\title{
OPEN Multiscale fluorescent tracking of immune cells in the liver with a highly biocompatible far-red emitting polymer probe
}

Malo Daniel ${ }^{1}$, Laurence Dubreil ${ }^{2}$, Romain Fleurisson ${ }^{2}$, Jean-Paul Judor ${ }^{1}$, Timothée Bresson ${ }^{3}$, Sophie Brouard ${ }^{1}$, Arnaud Favier ${ }^{3}$, Marie-Thérèse Charreyre ${ }^{3}$ \& Sophie Conchon ${ }^{1 \bowtie}$

The development of innovative immune cell therapies relies on efficient cell tracking strategies. For this, multiscale fluorescence-based analyses of transferred cells into the host with complementary techniques, including flow cytometry for high-throughput cell analysis and two-photon microscopy for deep tissue imaging would be highly beneficial. Ideally, cells should be labelled with a single fluorescent probe combining all the properties required for these different techniques. Due to the intrinsic autofluorescence of most tissues and especially the liver, far-red emission is also an important asset. However, the development of far-red emitting probes suitable for two-photon microscopy and compatible with clearing methods to track labelled immune cells in thick samples, remains challenging. A newly-designed water-soluble far-red emitting polymer probe, $19 \mathrm{~K}-6 \mathrm{H}$, with a large Stokes shift, was thus evaluated for the tracking of primary immune CD8 T cells. These cells, prepared from mouse spleen, were efficiently labelled with the $19 \mathrm{~K}-6 \mathrm{H}$ probe, which was internalized via endocytosis and was highly biocompatible at concentrations up to $20 \mu \mathrm{M}$. Labelled primary CD8 T cells were detectable in culture by both confocal and two-photon microscopy as well as flow cytometry, even after 3 days of active proliferation. Finally, 19K-6H-labelled primary CD8 T cells were injected to mice in a classical model of immune mediated hepatitis. The efficient tracking of the transferred cells in the liver by flow cytometry (on purified non-parenchymal cells) and by two-photon microscopy on $800 \mu \mathrm{m}$ thick cleared sections, demonstrated the versatility of the $19 \mathrm{~K}-6 \mathrm{H}$ probe.

Immune cell-based therapy is today considered as a major avenue for the regulation of immune responses in pathological situations such as cancer ${ }^{1}$ or transplantation ${ }^{2,3}$. In this context, the development of in vivo tracking of primary immune cells in animal model is of paramount importance to better understand the migration and behaviour of implanted cells in the host ${ }^{4}$. The main challenge in this field is to efficiently discriminate transferred cells from host tissue thanks to multiscale techniques including microscopy and flow cytometry. Therefore, optical strategies based on fluorescence detection have been developed, ranging from genetic engineering to exogenous labelling 5 . For this later purpose, various fluorescent probes have been designed for the labelling of immune cells prior to their engraftment ${ }^{6}$. Their most important properties should be: biocompatibility, as primary cells are fragile and difficult to maintain in an unaltered state prior to transfer; brightness and stability of the fluorescent signal, to ensure an efficient visualisation of the labelled cells over time. The range of absorption and emission wavelengths of the fluorescent probe is also critical considering the possible autofluorescence of the imaged tissue and the type of microscopy implemented for the tracking ${ }^{7}$. Fluorescence microscopy observations are often complicated by tissue autofluorescence, which mainly occurs in the UV and visible ranges, making far-red $(650-750 \mathrm{~nm})$ and near-infrared $(750-950 \mathrm{~nm})$ emission wavelengths highly attractive ${ }^{8-10}$. Moreover, when deep-tissue imaging of the transferred cells is desired, it is relevant to switch from one- to two-photon (2P) excited fluorescence (TPEF) microscopy ${ }^{11,12}$.

${ }^{1}$ Université de Nantes, INSERM, UMR1064, Centre de Recherche en Transplantation et Immunologie, ITUN, 44000 Nantes, France. ${ }^{2}$ PAnTher, INRAE, École nationale vétérinaire, agro-alimentaire et de l'alimentation Nantes-Atlantique (Oniris), Université Bretagne Loire (UBL), 44307 Nantes, France. ${ }^{3}$ Laboratoire Ingénierie des Polymères (IMP), CNRS UMR5223, Université Lyon1, Université de Lyon, Lyon, France. ${ }^{\varpi}$ email: sophie.conchon@ univ-nantes.fr 
TPEF-microscopy enables deep tissue imaging, as the near-infrared excitation by a pulsed laser induces less absorption and scattering in biological samples compared to the continuous visible light used in widefield and confocal microscopy ${ }^{13}$. The $2 \mathrm{P}$-excitation wavelength being almost twice the one-photon excitation value, it is very easy to efficiently separate the emitted fluorescence signal from the excitation light with appropriate filters. Another advantage of TPEF-microscopy is the low out-of-focus phototoxicity thanks to a highly localized excitation volume $\left(\sim 0.1 \mu \mathrm{m}^{3}\right)$ at the focal point of the laser and thus the high compatibility with in vivo biological analysis $^{14,15}$. In addition, no parasite fluorescence signal is generated below and above the focal plane. In order to further increase imaging penetration depth, several clearing protocols have been developed ${ }^{16}$. Most of them are based on tissue refractive index homogenization, and the resulting high tissue transparency drastically reduces light scattering in biological samples. Clearing protocol coupled with TPEF-microscopy enables an imaging depth of up to $4 \mathrm{~mm}$ in most tissues which is highly attractive to study tissue complexity and to image rare events.

One remaining challenge is to reconcile far-red fluorescence emission with a high $2 \mathrm{P}$-absorption for bioimaging. Indeed, most of the common far-red emitting fluorophores are efficiently excited in the 600-700 nm wavelength range, thus implying an optimal 2P-absorption above $1200 \mathrm{~nm}$ which is currently out of the range of standard femto-second pulse laser used on TPEF-microscopes used in core facilities. Therefore, fluorescent probes exhibiting a large Stokes shift (with excitation around $500 \mathrm{~nm}$ and emission in the far-red range) as well as high $2 \mathrm{P}$-absorption cross section values are highly desirable.

Far-red emitting nanoparticules ${ }^{17}$ have been synthesized in the last decade but with limited evidence of biocompatibility in primary cells or TPEF-microscopy applications. For instance, cell labelling with quantum dots (QDs), fluorescent inorganic semiconductor nanoparticules displaying unique optical features depending on their size, has recently emerged ${ }^{18}$. However, their cytotoxicity, mainly due to the liberation of free ions, is now well documented ${ }^{19,20}$. A new generation of far-red emitting QDs has been recently described to efficiently label breast cancer cell line in culture without cytotoxicity ${ }^{21}$. Primary cell or in vivo imaging and TPEF-microscopy applications have not been reported yet. Organic semiconducting polymer nanoparticules or dots (Pdots) represent the main competitor of QDs with an expected low intrinsic cytotoxicity ${ }^{22}$. Far-red emitting Pdots have been used for in vivo tumor imaging in mouse brain by confocal microscopy ${ }^{23}$ and very recently for multiphoton imaging of microvasculature in mice ${ }^{24}$. However, Pdots have not been used so far to label primary cells and their biocompatibility remains to be thoroughly investigated. Harmonic nanoparticles have been already described as powerful tool for muscle stem cell tracking in tissue ${ }^{25}$ but currently there is no flow cytometer capable to detect second harmonic generation. It is the reason why we have focused our interest on a different family of polymer probes offering a versatile alternative, compatible with both flow cytometry and various types of fluorescence microscopy investigations.

Such polymer probes are not nanoparticles but water-soluble polymer chains $\mathrm{s}^{26}$, bearing several far-red emitting fluorophores ${ }^{27}$ exhibiting large Stokes shifts (around $180 \mathrm{~nm}$ ) and high 2P-cross section values (around 440 $\mathrm{GM}$ in water for a similar fluorophore surrounded by a star-shaped polymer shell) ${ }^{28}$ for an efficient $2 \mathrm{P}$-absorption. They have a controlled chain structure (molecular weight, dispersity of the chains, number of fluorophores per chain, possible presence of an anchoring group like a lipid). Previous results demonstrated an efficient labelling of enveloped viruses ${ }^{29}$, living cells and zebrafish embryos ${ }^{30}$ with convenient TPEF-imaging and reported a low cytotoxicity on Jurkat and HeLa cell lines ${ }^{30}$. However, up until now, these polymer probes have not been used to label primary cells.

In this article, we investigated the newly designed far-red emitting polymer probe $19 \mathrm{~K}-6 \mathrm{H}$ for in vivo tracking of murine primary CD8 T lymphocytes (pCD8 T cells). This polymer probe bears an average of 6 fluorophores per chain and exhibits numerous carboxylate groups (up to 45 per chain) that contribute to its water-solubility. As opposed to previous probes of the same family, the chain is not terminated by a lipid group since preliminary tests showed that this structural characteristic was not necessary to get an efficient labelling of lymphocytes. The hydrodynamic diameter of this polymer probe that adopts a coil conformation in aqueous solution is estimated to be in the range of $5-8 \mathrm{~nm}^{31}$ (schematic representation in Fig. 1A, chemical structure in Figure $\mathrm{S} 1$ ). The absorption and fluorescence emission spectra of the polymer probe in water are provided in Figure S2.

We first thoroughly characterized the optical properties, the biocompatibility and the internalization route of the $19 \mathrm{~K}-6 \mathrm{H}$ probe in primary CD8 T cells. Then, we carried out evaluation of the $19 \mathrm{~K}-6 \mathrm{H}$ probe for tracking the labelled primary CD8 T cells in a mouse model of immune cell infiltration in the liver parenchyma, by confocal and TPEF-microscopy as well as by flow cytometry.

\section{Material and methods}

$19 \mathrm{~K}-6 \mathrm{H}$ polymer probe synthesis. All chemicals were purchased from Sigma-Aldrich at the highest purity available and used without further purification. Solvents were used as received, either from Fisher Scientific or Acros Organic. Poly( $\mathrm{N}$-acryloylmorpholine-co- $\mathrm{N}$-acryloxysuccinimide), P(NAM-co-NAS), copolymer chains (number average molecular weight $=19,400 \mathrm{~g} \mathrm{~mol}^{-1}$, dispersity $=1.07$ ) have been synthesized from a tertbutyl dithiobenzoate RAFT agent according to a previously reported process ${ }^{32}$. The organic fluorophore (isophorone derivative) has already been described ${ }^{27}$.

The synthesis of the $19 \mathrm{~K}-6 \mathrm{H}$ polymer probe was performed as follows: $25.1 \mathrm{mg}$ of P(NAM-co-NAS) copolymer were dissolved in $1 \mathrm{~mL}$ of chloroform in a round bottom flask equipped with a magnetic stirrer. Fluorophore ( $3.7 \mathrm{mg}$, dissolved in $0.5 \mathrm{~mL}$ of chloroform) was added together with 2 molar equivalents of triethylamine $(0.98 \mathrm{mg})$. Polymer concentration was adjusted to $10 \mathrm{mg} \mathrm{mL}^{-1}$ with chloroform. The reaction was carried out at $30^{\circ} \mathrm{C}$ in the dark under stirring for $2 \mathrm{~h}$. The binding yield was followed by size exclusion chromatography (SEC) with a UV-Visible detector according to a previously described method ${ }^{33}$ and reached $75 \%$ (corresponding to an average of 6 fluorophores per polymer chain). In order to eliminate the residual fluorophores, the mixture was precipitated in a large volume of diethyl ether and the fluorescent polymer was recovered as a powder by 
centrifugation $\left(10,000 \mathrm{t} \mathrm{min}^{-1}, 10 \mathrm{~min}, 4^{\circ} \mathrm{C}\right)$. The procedure was repeated until full discoloration of the supernatant. The fluorescent polymer was finally dried under vacuum.

Hydrolysis of the residual succinimide ester units along the polymer chain was carried out using $50 \mathrm{~mL}$ of borate buffer $(50 \mathrm{mM}, \mathrm{pH}=9.3$ ) directly added to $25 \mathrm{mg}$ of the fluorescent polymer, and let at room temperature under stirring for $48 \mathrm{~h}$. Then, the fluorescent polymer was purified by dialysis (SPECTRUM LABS, Spectra/Por 6, MWCO: $2000 \mathrm{~g} \mathrm{~mol}^{-1}$ ) against deionized water (2 baths) and milliQ water (1 bath). The dark-red-colored fluorescent polymer was dried by lyophilization. After this hydrolysis step, the polymer probe exhibits numerous carboxylate groups $\left(-\mathrm{COO}^{-}\right)$along the polymer chain: a maximum of 45 per chain (depending on the $\mathrm{pH}$ and on the distribution of these groups). Consequently, the molecular weight of the polymer chain (under the -COONa form) decreased to $17,500 \mathrm{~g} \mathrm{~mol}^{-1}$.

Characterization of the $19 \mathrm{~K}-6 \mathrm{H}$ polymer probe. Size exclusion chromatography (with a UV-Visible detector), absorption and fluorescence emission spectra were recorded as previously described ${ }^{26}$. The molar extinction coefficient $(\varepsilon)$ of the polymer probe and its fluorescence quantum yield $(\phi)$ in water were determined, following a previously described protocol ${ }^{33}$, from the absorption and emission spectra, respectively $\left(\varepsilon=43,400 \pm 700 \mathrm{~mol}^{-1} \mathrm{~L} \mathrm{~cm}^{-1}\right.$ at $\lambda_{\text {abs max }}=504 \mathrm{~nm} ; \phi=0.064$ at $\left.\lambda_{\mathrm{ex}}=510 \mathrm{~nm}\right)$. Reference was erythrosin B in methanol $\left(\phi=0.09\right.$ at $\left.\lambda_{\mathrm{ex}}=510 \mathrm{~nm}\right)$. Therefore, the brightness $(\varepsilon \cdot \phi)$ of the polymer probe in water was calculated to be $2800 \mathrm{~mol}^{-1} \mathrm{~L} \mathrm{~cm}^{-1}$.

Mice. Male C57Bl/6 mice were purchased from JANVIER LABS (France), used between 7 and 12 weeks of age and housed at the UTE IRS-UN (Nantes-France) animal facilities. Mice were fed ad libitum and allowed continuous access to tap water. All procedures were approved by the regional ethical committee for animal care and use and by the French Ministry of Research (agreement APAFIS \#13742). All experiments were performed in accordance with relevant guidelines and regulations.

Tissue and cell preparations. Livers were PFA-fixed for $48 \mathrm{~h}$ or included in OCT Compound (TISSUETEK) and frozen in liquid nitrogen $\left(-196^{\circ} \mathrm{C}\right)$-cooled isopentane after in vivo elimination of blood by perfusion of HBSS $1 \times$ buffer (GIBCO). For confocal imaging, frozen liver samples were acetone-fixed and cryo-sectioned at $15 \mu \mathrm{m}$ then analysed on the laser confocal scanning microscope LSM780 ZEISS (CARL ZEISS MICROSCOPY, Jena, Germany). For multiphoton imaging, PFA-fixed liver samples were sectioned with a scalpel to get $0.8-1 \mathrm{~mm}$ thick sections then cleared by using CUBIC protocol and analysed on the A1R-MP NIKON multiphoton microscope (technical parameters below).

Liver non-parenchymal cells (NPC) were isolated as previously described ${ }^{34}$. Briefly, after perfusion with HBSS $1 \times$ buffer (GIBCO), livers were digested with collagenase IV (SIGMA-ALDRICH-C5138) and NPC enriched by Percoll (GE HEALTHCARE-17-0891-01) density gradient centrifugation and red blood cells lysis.

pCD8 T cells used in biocompatibility, labelling study and adoptive transfer experiments were isolated from C57Bl/6 mice spleen after red blood lysis (ACK buffer: $\mathrm{NH}_{4} \mathrm{Cl} 155 \mathrm{mM}, \mathrm{KHCO}_{3} 10 \mathrm{mM}$ EDTA $0.1 \mathrm{mM}$ ) and negatively sorted with MILTENYI CD8 $\mathrm{a}^{+} \mathrm{T}$ cell isolation kit (130-104-075).

CUBIC clearing. Clearing of $800 \mu \mathrm{m}$ PFA-fixed sections were performed with the CUBIC Protocol I for Adult Mouse Organ Samples and Marmoset Brain described by Tainaka et al. ${ }^{35}$. PFA-fixed livers were washed with gentle shaking in PBS for $15 \mathrm{~h}$ at room temperature then incubated in CUBIC-L (TCI - T3740) for 4 days with gentle shaking at $37^{\circ} \mathrm{C}$. After another PBS wash, organ sections were incubated with 1:1 water-diluted CUBIC-R+ (TCI - T3741) with gentle shaking for 1 day at room temperature then in CUBIC-R+ for one more day in the same conditions.

In vitro biocompatibility assay. pCD8 cells were cultured during 5 days (from Day 0 to Day 4) in RPMI medium (GIBCO-31870074) supplemented with 10\% FBS, 1\% Penicillin/Streptomycin, 1\% Glutamine, $10 \mathrm{mM}$ Hepes (GIBCO-15630056), $1 \mathrm{mM}$ Sodium Pyruvate (GIBCO-11360039), $1 \times$ Non-Essential Aminoacids (GIBCO-11140035) and $50 \mu \mathrm{M}$ 2-mercaptoethanol (SIGMA-ALDRICH-M6250). From Day 0 to Day 1, pCD8 T cells were incubated with increasing concentrations of $19 \mathrm{~K}-6 \mathrm{H}$ probe $(0 ; 0.5 ; 5 ; 20 \mu \mathrm{M})$. On Day 1 , cells were washed and resuspended in complete RPMI medium, with IL-2 (CELLGENIX $10 \mathrm{U} \mathrm{mL}^{-1}$ ) and T activator CD3/CD28 Dynabeads (GIBCO-ratio cell/bead 1:1) to induce their proliferation. Cells were analysed on LSR II flow cytometer (BECTON DICKINSON). Viability and proliferation were monitored with the LIVE/DEAD Fixable Yellow Dead Cell Stain Kit (INVITROGEN) and 123 count eBeads Counting Beads (INVITROGEN), respectively. The cell activation state was analysed by flow cytometry with antibodies directed towards early activation marker CD69 (FITC_BD 553236), and late activation markers CD44 (APC-BD 559250) and CD25 (PE-BD 553866).

Characterization of 19K-6H labelling on primary immune cells. pCD8 T cells were prepared as described above. From Day 1 to Day 4, cells were plated in chambered coverslips (IBIDI $\mu$-Slide 18 well81826-15,000 cells/well) coated with Poly-L-Lysine (SIGMA-ALDRICH-P4707) then imaged on the laser confocal scanning microscope LSM780 ZEISS (CARL ZEISS MICROSCOPY, Jena, Germany) at 63× magnification. Transmission light was used to localize the cells and laser line $561 \mathrm{~nm}$ to analyse the $19 \mathrm{~K}-6 \mathrm{H}$ fluorescence. Spectral detection was performed with ZEISS 32 Channel GaAsP spectral detectors and images analysed with FIJI image analyse software. A minimum of 100 cells were imaged for each condition. 
Internalization pathway investigation. HeLa cells (ATCC CCL-2) were cultured in DMEM medium (GIBCO-11960085) supplemented with 10\% FBS, 1\% Penicillin/Streptomycin and 1\% Glutamine. The cells ( $50 \%$ of confluency) were transfected with $100 \mathrm{ng}$ of Rab5a-mCherry ${ }^{36}$ or Rab7-GFP ${ }^{37}$ plasmids, preincubated with $0.5 \mu \mathrm{L}$ Lipofectamine (INVITROGEN-15338100), during $24 \mathrm{~h}$ at $37^{\circ} \mathrm{C}$ in complete DMEM as described above (without Penicillin/streptomycin). Cells were then washed and plated in chambered coverslips (IBIDI $\mu$-Slide 18 well-81826-3000 cells/well) and allowed to adhere overnight. Nuclei were counterstained with Hoechst 33342 (THERMOFISHER-H1399) diluted at 1:2000 in complete DMEM medium during 10 min at $37^{\circ} \mathrm{C}$. Medium was carefully replaced with complete DMEM containing $10 \mu \mathrm{M}$ of $19 \mathrm{~K}-6 \mathrm{H}$ probe right before imaging. Confocal imaging was performed with the laser confocal scanning microscope LSM780 ZEISS (CARL ZEISS MICROSCOPY, Jena, Germany) at $63 \times$ magnification. $405 \mathrm{~nm}, 488 \mathrm{~nm}$ and $561 \mathrm{~nm}$ laser lines was used to excite Hoechst 33342, GFP, mCherry and 19K-6H probe, respectively. Spectral detection was performed with ZEISS 32 Channel GaAsP spectral detectors and images analysed with FIJI image analyse software.

Inhibition of endocytosis was performed by pre-incubating HeLa cells or pCD8 T cells at $4{ }^{\circ} \mathrm{C}$ or in presence of $80 \mu \mathrm{M}$ Dynasore ${ }^{38}$ (SIGMA-ALDRICH-D7693) or DMSO (Dynasore-vehicle-SIGMA-ALDRICH-276855) for $1 \mathrm{~h}$. Cells were then incubated $8 \mathrm{~h}$ with $19 \mathrm{~K}-6 \mathrm{H}$ probe, at $4{ }^{\circ} \mathrm{C}$ or in presence of $80 \mu \mathrm{M}$ Dynasore or DMSO. $19 \mathrm{~K}-6 \mathrm{H}$ internalization was assessed by flow cytometry.

pCD8 1 cell adoptive transfer. pCD8 T cell isolated from C57Bl/6 mice were incubated overnight in complete RPMI medium, with IL-2 (CELLGENIX $10 \mathrm{U} \mathrm{mL}^{-1}$ ) and activator antibodies : $1 \mu \mathrm{g} \mathrm{mL} \mathrm{m}^{-1}$ anti-CD3 (BD 553057 - coated) and $1 \mu \mathrm{g} \mathrm{mL}{ }^{-1}$ anti-CD28 (BD 553294), with or without $20 \mu \mathrm{M}$ of $19 \mathrm{~K}-6 \mathrm{H}$ probe $\left(1.5 \times 10^{7}\right.$ cells and $0.5 \times 10^{7}$ cells respectively). The next day, cells are washed in PBS $1 \times$ then injected i.v. in 2 C57Bl/6 mice for systemic delivery. Recipient mice are then injected i.v. with $15 \mathrm{mg} \mathrm{kg}^{-1}$ Concanavalin A (SIGMA-ALDRICHC2010) to induce a T cell-mediated acute liver hepatitis ${ }^{39}$. Mice were then sacrificed and livers and NPC were prepared as described above. Tissues were analysed by both confocal and TPEF-microscopy as described above. Cells were analysed on LSR II flow cytometer (BECTON DICKINSON) with antibodies directed towards CD3 (V450-BD 560801), CD8 (APC-BD 553035) and CD69 (FITC-BD 553236) markers. 19K-6H fluorescence was detected in the Pe-Cy5.5 channel $\left(\lambda_{\mathrm{ex}} 561 \mathrm{~nm}, \lambda_{\mathrm{em}} 710 / 50 \mathrm{~nm}\right)$.

Confocal microscopy. The inverted laser scanning microscope LSM780 ZEISS (CARL ZEISS MICROSCOPY, Jena, Germany) was equipped with solid state lasers 405, 561 and $633 \mathrm{~nm}$ and argon laser 455, 488, $514 \mathrm{~nm}$ and ZEISS 32 Channel GaAsP spectral detectors. Spectral sequences of 32 images were obtained using $8 \mathrm{~nm}$ band pass filters in the 405-700 $\mathrm{nm}$ range. Linear unmixing process of data obtained from spectral imaging was performed for matching the spectral variations in the lambda stack of the cells labelled with the $19 \mathrm{~K}-6 \mathrm{H}$ probe and autofluorescence spectra recorded from control specimen (unstained cells and non-injected liver). The objectives used were Immersion 63X objective lens (NA 1.4 Oil DIC Plan-Apochromat) and 20× objective lens (NA 0.8 Plan-Apochromat).

Two-photon imaging. The A1R-MP NIKON microscope was equipped with an Insight Deepsee laser from SPECTRA-PHYSICS, tunable in the $680-1300 \mathrm{~nm}$ range, $<120 \mathrm{fs}$ pulse width with a dual output at $1040 \mathrm{~nm}$ for simultaneous two-photon imaging. The system was equipped with three high sensitive channels GaAsp Non Descanned Detectors (NDD) and one supplementary channel PMT NDD. Auto laser alignment was performed when changing multiphoton excitation wavelength. The configuration of the filters attached to NDD were (1) band-width 400-492 nm, (2) band-width (500-550 nm), (3) band-width (563-588 nm), (4) band-width (601$657 \mathrm{~nm}$ ). The immersion objective used was an apochromat $25 \times$ MP1300 objective lens (NA 1.10, WD $2.0 \mathrm{~mm}$ ).

\section{Results}

Fluorescence imaging of murine primary CD8 T cells labelled with $19 \mathrm{~K}-6 \mathrm{H}$ probe. The synthesis and characterization of the $19 \mathrm{~K}-6 \mathrm{H}$ polymer probe (Fig. 1A) are presented in the "Material and methods" section. The labelling of murine primary $\mathrm{CD}^{+} \mathrm{T}$ lymphocytes (pCD8 T cells) isolated from C57Bl/6 mice spleen with the $19 \mathrm{~K}-6 \mathrm{H}$ probe was first assessed by fluorescence imaging. Freshly isolated pCD8 T cells were incubated overnight ( $15 \mathrm{~h}$ ) with $20 \mu \mathrm{M}$ of the $19 \mathrm{~K}-6 \mathrm{H}$ polymer probe and imaged by confocal spectral microscopy. Four different excitation wavelengths $(405,488,561,633 \mathrm{~nm})$ were tested to identify the best excitation/emission wavelengths for the visualisation of the probe (Fig. 1B). Emission spectra were recorded for the $488 \mathrm{~nm}$ and $561 \mathrm{~nm}$ excitation wavelengths and showed emission peaks at $650 \mathrm{~nm}$ and $660 \mathrm{~nm}$, respectively (Fig. 1C). Spectral acquisitions for the $561 \mathrm{~nm}$ excitation wavelength that provided the highest fluorescence signal (Fig. 1B) confirmed a maximal emission around $650 \mathrm{~nm}$ (Figure S3), and this excitation was chosen for further confocal microscopy analyses. Morphologically, the $19 \mathrm{~K}-6 \mathrm{H}$ signal appears intracytoplasmic and displays a specific subcellular localisation profile, with spots of high fluorescence intensity (diameter: $0.86 \mu \mathrm{m} \pm 0.55$ ), suggesting an accumulation in vesicles. TPEF-microscopy on labelled primary CD8 T cells was performed after an overnight incubation with $20 \mu \mathrm{M}$ of $19 \mathrm{~K}-6 \mathrm{H}$ probe then nuclear counterstained. The $1040 \mathrm{~nm}$ excitation wavelength gave the best signal-to-noise ratio (data not shown) and resulted in strong fluorescence signal in the red/NIR channel around the nucleus of the 19K-6H labelled cells (Fig. 1C) with an absence of signal in the negative control (pCD8 T cells without 19K-6H probe, Fig. 1D).

Stability of $19 \mathrm{~K}-6 \mathrm{H}$ labelling in primary immune cells. The stability of the primary cell labelling with the $19 \mathrm{~K}-6 \mathrm{H}$ probe was assessed in conditions of cell proliferation. pCD8 T cells isolated from splenocytes of $\mathrm{C} 57 \mathrm{Bl} / 6$ mice were incubated for $15 \mathrm{~h}$ with increasing concentrations of $19 \mathrm{~K}-6 \mathrm{H}$ probe (0 to $20 \mu \mathrm{M})$. Cells were 
A
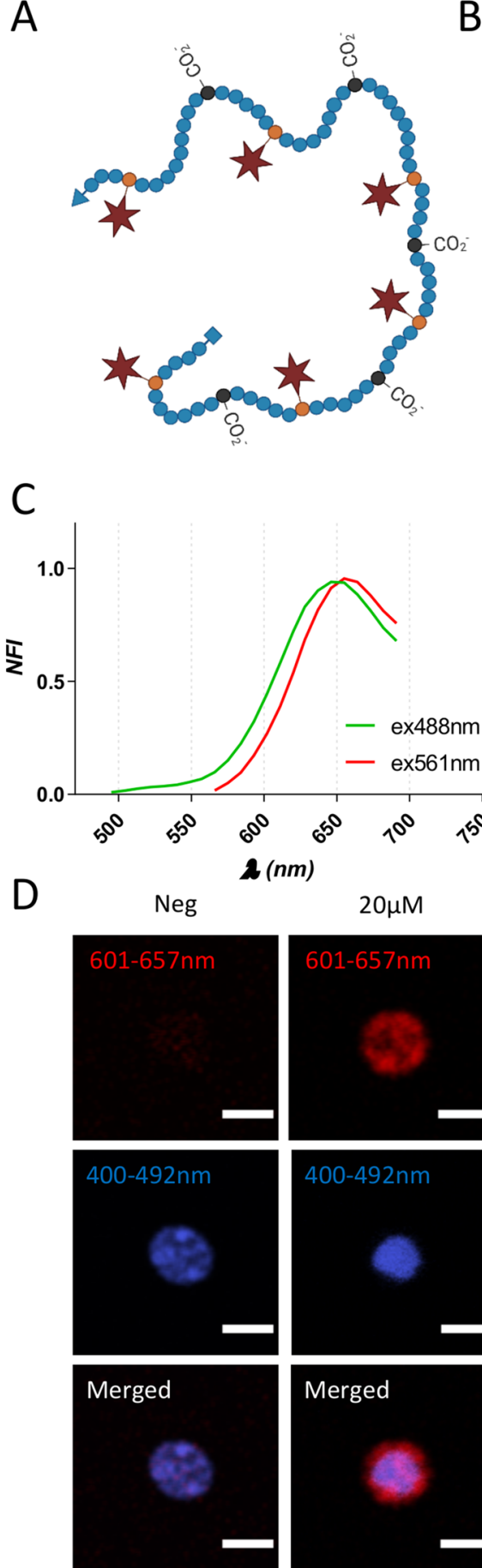

$20 \mu \mathrm{M}$
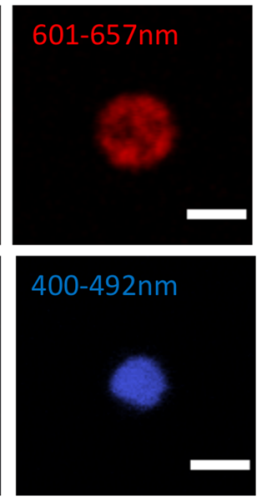

Merged
B
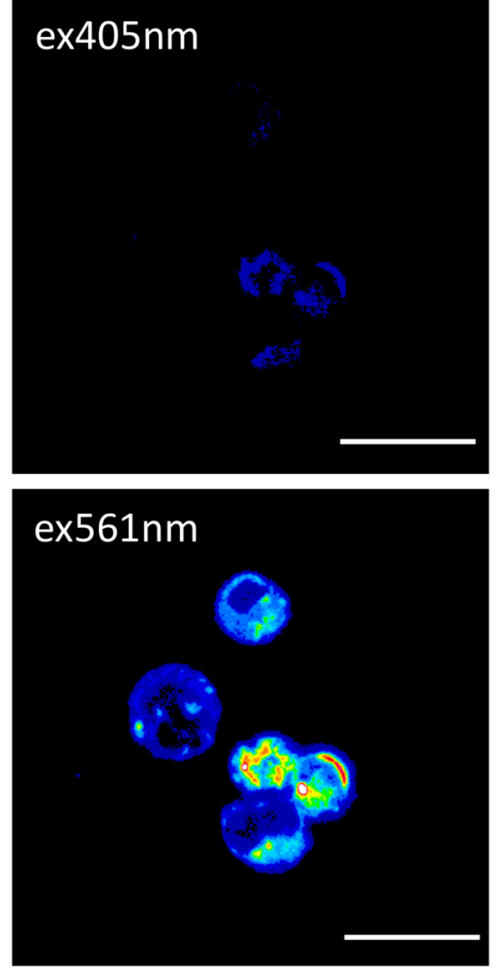

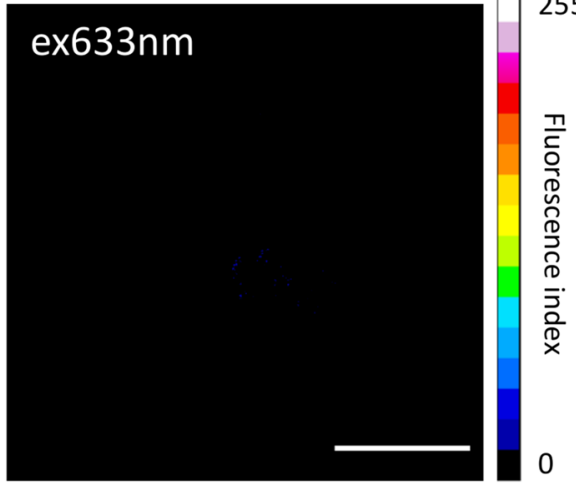

Figure 1. (A) Schematic representation of the $19 \mathrm{~K}-6 \mathrm{H}$ polymer probe. (B) Confocal spectral imaging (objective $\times 63)$ of living pCD8 T cells labelled with $19 \mathrm{~K}-6 \mathrm{H}$ probe $(20 \mu \mathrm{M}, 15-\mathrm{h}$ incubation) from excitation at $405 \mathrm{~nm}$, $488 \mathrm{~nm}, 561 \mathrm{~nm}$ and $633 \mathrm{~nm}$. Each image is a representation of maximum intensity projection obtained between 566 and $700 \mathrm{~nm}$. Grey levels (8bits) were color-coded with the 16 colors look-up-table (LUT) from FIJI. Scale bar: $10 \mu \mathrm{m}$. (C) Emission spectra of 19K-6H in cellulo, from 488 and $561 \mathrm{~nm}$ excitation, determined with spectral imaging (fluorescence intensity collected every $8.9 \mathrm{~nm}$ between 566 and $700 \mathrm{~nm}$ ). (D) TPEF-imaging (objective $\times 25$ ) of living pCD8 T cells counterstained with Hoechst nuclear probe, labelled with $19 \mathrm{~K}-6 \mathrm{H}$ probe (20 $\mu \mathrm{M}, 15-\mathrm{h}$ incubation) (top panel) compared to negative control (bottom panel, only Hoechst nuclear probe). Dual sequential excitation at $900 \mathrm{~nm}$ and $1040 \mathrm{~nm}$ for respective observation of nuclear Hoechst staining (blue channel, 400-492 nm) and internalized 19K-6H probe (red channel, 601-657 nm). Fluorescent images (visualized in blue and red, false colors) are presented separately on left and middle panel and merged on right panel. Scale bar: $5 \mu \mathrm{m}$. 
then washed and cultured for 4 days (from Day 1 to Day 4) in the presence of stimulatory signals (anti-CD3/ anti-CD28 agonists and Interleukin-2 (IL-2)) to induce their activation and proliferation (Fig. 2A). The 19K-6H labelling was assessed by confocal spectral microscopy at $561 \mathrm{~nm}$ excitation from Day 1 (before activation) to Day 4, then analysed with the FIJI software. First, after a 15-h incubation at the highest probe concentrations $(20$ and $5 \mu \mathrm{M}), 95 \%$ of cells were labelled, whereas only $30 \%$ were labelled for the $0.5 \mu \mathrm{M}$ concentration (data not shown). The intracellular fluorescence increased proportionally from 0.5 to $5 \mu \mathrm{M}$ (MFI from $33.61 \pm 2.81$ to $306.5 \pm 41.39$ ), and reached a maximum for the $20 \mu \mathrm{M}$ condition (MFI: $503 \pm 57.89$ (Fig. $2 \mathrm{~B}$ ). From Day 1 to Day 4 , in the presence of anti-CD3/anti-CD28 agonists and IL-2, a progressive decrease of the 19K-6H-labelled pCD8 $\mathrm{T}$ cell fluorescence was observed, concurrently with their proliferation (Fig. 2C, Figure S4). On Day 4, while pCD8 $\mathrm{T}$ cells had divided at least twice, those labelled with $5 \mu \mathrm{M}$ and $20 \mu \mathrm{M}$ of $19 \mathrm{~K}-6 \mathrm{H}$ probe were still detectable (MFI: $73.80 \pm 10.21$ and $84.4 \pm 11.94$ respectively). These results were confirmed by flow cytometry experiments (Figure S5). Spectral microscopy analysis of the fluorescence within cells demonstrated the very stable emission profile of the $19 \mathrm{~K}-6 \mathrm{H}$ probe, with identical emission spectrum over time (Fig. $2 \mathrm{D}$ ). These results showed that the $19 \mathrm{~K}-6 \mathrm{H}$ probe, used at $5 \mu \mathrm{M}$ to $20 \mu \mathrm{M}$ concentrations, optimally labelled pCD8 T cells and enable detection even after 3 days of active proliferation. Moreover, no events indicative of a potential cytotoxicity (e.g. plasma membrane blebbing, cell shrinkage) were observed, even at the highest $19 \mathrm{~K}-6 \mathrm{H}$ concentration tested $(20 \mu \mathrm{M})$.

19K-6H polymer probe biocompatibility. Following the same experimental protocol (Fig. 2A), the innocuity of the $19 \mathrm{~K}-6 \mathrm{H}$ polymer probe was further investigated on the cellular biology of pCD8 T cells isolated from the spleen of $\mathrm{C} 57 \mathrm{Bl} / 6$. The proliferation, viability and expression of activation markers were assessed by flow cytometry from Day 0 (before adding $19 \mathrm{~K}-6 \mathrm{H}$ ) to Day 4 . The $19 \mathrm{~K}-6 \mathrm{H}$ polymer probe did not induce either short-term or long-term cell mortality. More than $70 \%$ of the cells remained alive $15 \mathrm{~h}$ post-incubation (Day 1 ) with $19 \mathrm{~K}-6 \mathrm{H}$ probe, even at the highest $20 \mu \mathrm{M}$ concentration, similarly to what was measured for the primary cells incubated without the probe (Fig. 3A).

In addition, the $19 \mathrm{~K}-6 \mathrm{H}$ probe did not alter $\mathrm{pCD} 8 \mathrm{~T}$ cells proliferation in response to the mitogenic signals. After 4 days of culture, the viability and proliferation of pCD8 T cells shared the same trend, independently of the $19 \mathrm{~K}-6 \mathrm{H}$ concentration, with approximately $8 \times 10^{5}$ cells and $60 \%$ of cell viability (no statistical differences).

Potential effect of $19 \mathrm{~K}-6 \mathrm{H}$ probe on cell activation was studied before and after adding mitogenic signals (i.e. anti-CD3/anti-CD28 agonists and IL-2) in the culture medium. Expression of CD69, an early and transient activation marker, and of CD44 and CD25, late activation markers, were analysed at different time points by flow cytometry (Fig. 3B, and detailed histograms in Figure S6). After a 15-h incubation with the 19K-6H probe from 0 to $20 \mu \mathrm{M}$, there was no significant difference in the expression of activation markers by pCD8 T cells. In line with what was previously observed by confocal microscopy for cell viability and proliferation, the $19 \mathrm{~K}-6 \mathrm{H}$ probe did not alter the activation of pCD8 T cells in response to mitogenic factors. For each tested concentration, the expression of CD69 marker in pCD8 T cells reached a peak of $80 \%$ by Day 2 and then progressively decreased to the basal level by Day 4. CD 44 and CD25 were expressed respectively by $95 \%$ and $80 \%$ of cells by Day 4, comparable to what was measured for cells incubated without the probe.

Altogether, these results demonstrated that a 15-h incubation of pCD8 T cells with the $19 \mathrm{~K}-6 \mathrm{H}$ probe did not induce short- or long-term cytotoxicity or cell activation, even at $20 \mu \mathrm{M}$. In addition, the $19 \mathrm{~K}-6 \mathrm{H}$ probe did not disrupt nor alter the activation and proliferation abilities of the pCD8 T cells in response to mitogenic signals for 3 days.

19K-6H polymer probe internalization pathway. $19 \mathrm{~K}-6 \mathrm{H}$-labeled pCD8 T cells displayed a heterogeneous subcellular distribution with vesicular spots of high fluorescence intensity, which suggested an internalization process via endocytosis. In order to investigate this possibility, we used a previously described model of transfected cells specifically expressing fluorescent proteins in the endosomal compartment ${ }^{36,37}$. HeLa cells were transfected with plasmids coding for early (Rab5a) or late (Rab7) endosomal markers fused with mCherry or GFP fluorescent proteins, respectively. $19 \mathrm{~K}-6 \mathrm{H}$ probe was added $24 \mathrm{~h}$ after transfection and time-lapse acquisition was performed using spectral confocal microscopy. As shown in Fig. 4A, more than 95\% of intracellular $19 \mathrm{~K}-6 \mathrm{H}$ probe was found within Rab5a-mCherry positive early endosomes in the very first minutes after addition to the culture medium. After $2 \mathrm{~h}$ of incubation, the $19 \mathrm{~K}-6 \mathrm{H}$ probe colocalized strongly with Rab7-GFP labelled late endosomes (Fig. 4B). Finally, even after a 24-h incubation, no 19K-6H fluorescence signal was detected in the nucleus of the HeLa cells (Fig. 4C). In a control experiment, endocytosis was then blocked either by incubating the cells at $4{ }^{\circ} \mathrm{C}$ or by adding Dynasore that inhibits dynamin, a key protein for several pathways of endocytosis, including clathrin-mediated endocytosis and other dynamin-dependent mechanisms $\mathrm{s}^{38}$. $19 \mathrm{~K}-6 \mathrm{H}$ internalization was reduced by $90 \%$ and $40 \%$ respectively, confirming that the probe is mainly internalized by endocytosis (Fig. 4D). The same experiment performed on pCD8 T cells gave similar results (Figure S7).

Adoptive transfer of $19 \mathrm{~K}-6 \mathrm{H}$ labelled pCD8 T cells in a mouse model of immune-mediated hepatitis. In order to demonstrate the interest of $19 \mathrm{~K}-6 \mathrm{H}$ labelling for in vivo tracking of primary immune cells following their adoptive transfer, we used a classical mouse model of $\mathrm{T}$ cell-induced liver injury, in response to Concanavalin A (ConA) injection ${ }^{39}$. pCD8 $\mathrm{T}$ cells were prepared from donor mice, and incubated overnight with or without the $19 \mathrm{~K}-6 \mathrm{H}$ probe $(20 \mu \mathrm{M}) .0 .5$ to $1.5 \times 10^{7} \mathrm{pCD} 8 \mathrm{~T}$ cells (control or $19 \mathrm{~K}-6 \mathrm{H}$ labelled) were injected intravenously to recipient mice, followed $1 \mathrm{~h}$ later by a single injection of ConA, or PBS (Fig. 5A). Mice were sacrificed $3 \mathrm{~h}$ later, and liver non-parenchymal cells (NPC) which include infiltrating leukocytes, were prepared and analysed by flow cytometry. Fragments of liver were also frozen and PFA-fixed for further confocal and TPEF-microscopy imaging, respectively. As expected, the ConA injection induced an enhanced recruitment 


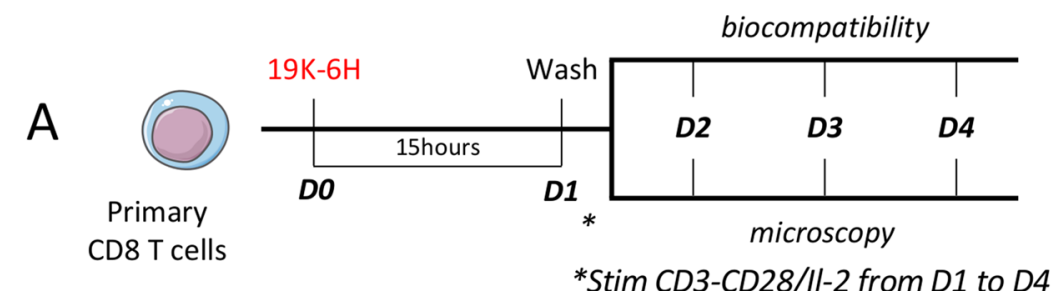

*Stim CD3-CD28/II-2 from D1 to D4

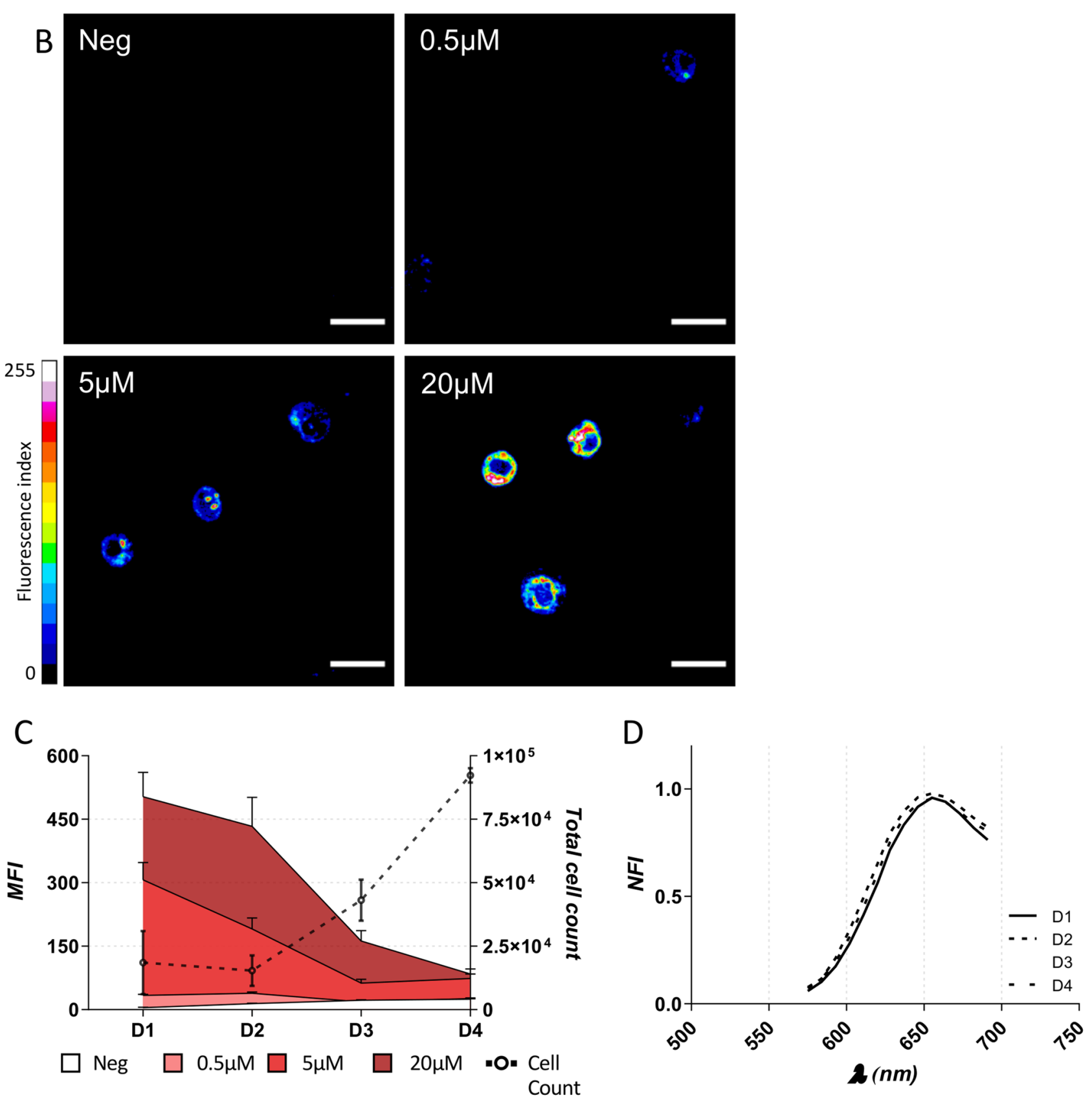

Figure 2. (A) pCD8 T cells are incubated overnight with $19 \mathrm{~K}-6 \mathrm{H}$ probe then washed and resuspended in complete medium with stimulating signal. 19K-6H labelling and biocompatibility are analysed by confocal microscopy and flow cytometry respectively, from day 1 (D1) to day 4 (D4) post-incubation. (B) Fluorescence confocal microscopy images (objective $\times 63$ ) of pCD8 T cells $\left(\lambda_{\mathrm{ex}} 561 \mathrm{~nm}\right)$, after $15 \mathrm{~h}$ (D1) incubation with increasing concentrations of $19 \mathrm{~K}-6 \mathrm{H}$ probe $(0 \mu \mathrm{M}, 0.5 \mu \mathrm{M}, 5 \mu \mathrm{M}, 20 \mu \mathrm{M})$. Grey levels (8bits) were color-coded with the 16 colors look-up-table (LUT) from FIJI. Scale bar: $10 \mu \mathrm{m}$. (C) Evolution of 19K-6H labelling on proliferating pCD8 T cells from day 1 (D1) to day 4 (D4) after $15 \mathrm{~h}$ incubation of the $19 \mathrm{~K}-6 \mathrm{H}$ probe at different concentrations. Mean Fluorescence intensity was measured on 100 to 1000 cells by condition. (D) Emission spectra of $19 \mathrm{~K}-6 \mathrm{H}$ in cellulo on proliferating pCD8 T cells, D1, D2, D3 and D4 after cells labelling. MFI: mean fluorescence intensity; NFI: normalized fluorescence intensity. 

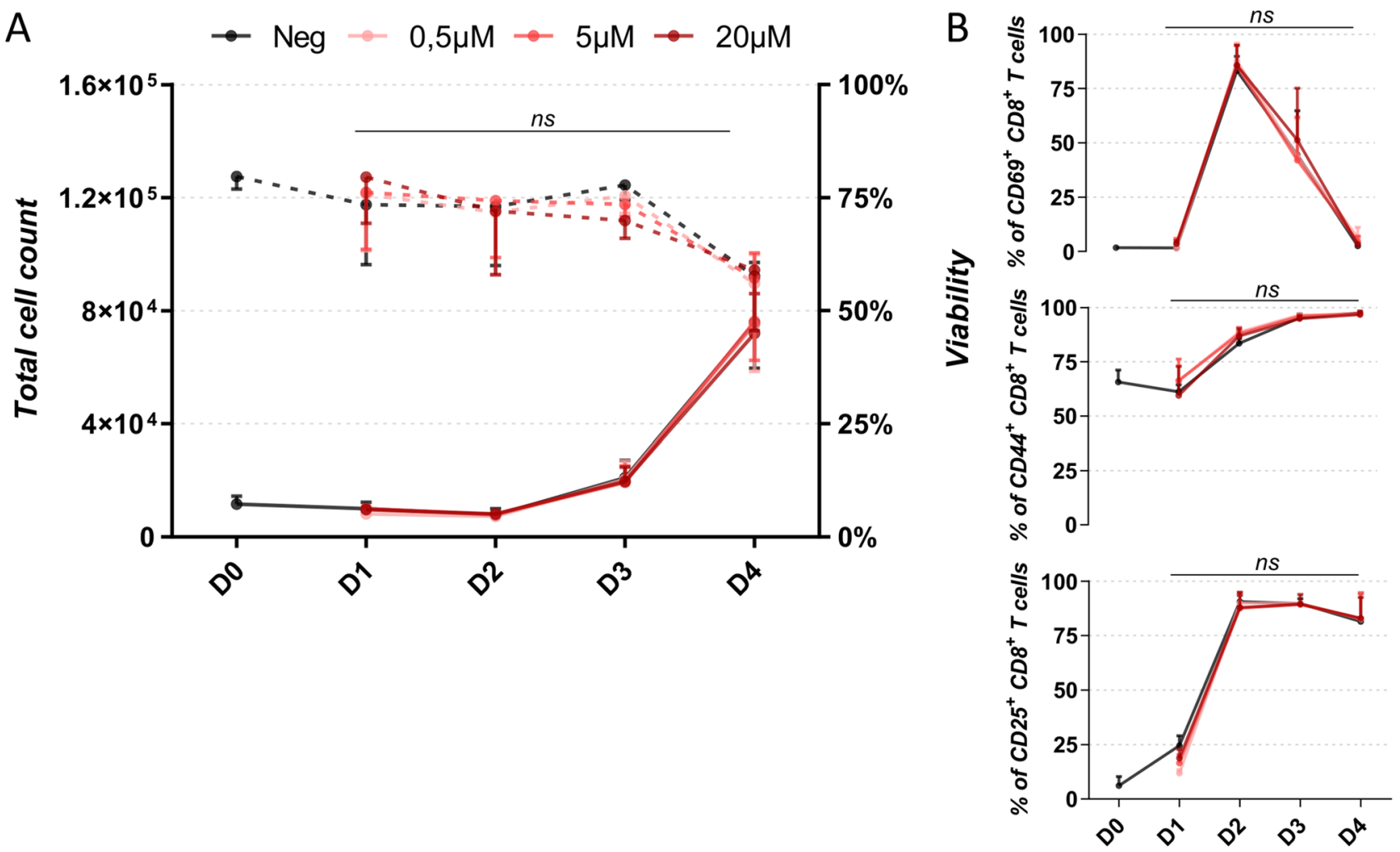

Figure 3. (A) Evolution of proliferation and viability of pCD8 $\mathrm{T}$ cells after $15 \mathrm{~h}$ incubation with increasing concentrations $(0.5,5,20 \mu \mathrm{M})$ of $19 \mathrm{~K}-6 \mathrm{H}$ probe compared to negative control (w/o $19 \mathrm{~K}-6 \mathrm{H})$. Full line: total cell count (left Y axis); dotted line: percentage of living cells (right Y axis). (B) Evolution of the expression of CD69, CD44 and CD25 activation markers. $\mathrm{n}=3$. The error bars indicate the standard deviation calculated for the averages from the three experiments. Significance is calculated by Two-Way Anova test; ns: non-significant.

of CD8 T cells to the liver, which are all in a CD69+ activated state, as shown by flow cytometry analysis (Fig. 5B). In mice that received ConA after adoptive transfer of 19K-6H-labelled pCD8 T cells, $18 \%$ of total liver CD8 T cells were 19K-6H positive (Fig. 5C). Confocal spectral microscopy analysis was performed on $15 \mu \mathrm{m}$ frozen liver sections; far-red emitting cells were detected only in the liver of mice that had received 19K-6H labelled pCD8 T cells, however in very limited numbers (Fig. 5D). In order to acquire a higher number of events, and thanks to the high $2 \mathrm{P}$-absorption of the $19 \mathrm{~K}-6 \mathrm{H}$ probe, we then performed TPEF-microscopy for deep imaging.

TPEF-microscopy was carried out on $800 \mu \mathrm{m}$ PFA-fixed liver sections, in order to get a more representative investigation of the pCD8 $\mathrm{T}$ cell infiltration within the liver. The sections were first cleared following CUBIC protocol $^{35,40}$ to increase transparency (Fig. 6A), allowing a deeper (up to $4 \mathrm{~mm}$ ) and less noisy imaging. Since the $19 \mathrm{~K}-6 \mathrm{H}$ probe was efficiently excited at $1040 \mathrm{~nm}$ and enabled TPEF-imaging of labelled pCD8 T cells in vitro (Fig. 1C), the same wavelength was used to localize 19K-6H-labelled pCD8 T cells in $800 \mu \mathrm{m}$ cleared liver sections and the $900 \mathrm{~nm}$ excitation wavelength was used to image the tissue autofluorescence. The individual images acquired from these 2 independent excitations (900 nm and $1040 \mathrm{~nm}$ ) and collected in 2 independent channels (green and red channel respectively), and the overlay are presented on Fig. 6B. No liver autofluorescence was detected in red channel at $1040 \mathrm{~nm}$ excitation wavelength. For the liver of mice injected with $19 \mathrm{~K}-6 \mathrm{H}$-labelled pCD8 T cells, the reconstructed 3D image displayed a significant number of far-red emitting events (with variable volume and brightness), contrary to what was observed with the liver of mice injected with unlabelled pCD8 T cells (Fig. 6B). Quantification was carried out to confirm these observations and to characterize the detected events in terms of number, volume and distribution over the $900 \mu \mathrm{m}$ depth of the sections. A total volume of $0.186 \mathrm{~mm}^{3}\left(500 * 500^{\star} 800 \mu \mathrm{m}\right)$ of the cleared liver of mice injected with labelled pCD $8 \mathrm{~T}$ cells was probed by 8 independent and non-overlapping analyses (each of $0.0232 \mathrm{~mm}^{3}-$ Fig. 7A), using the 3D measurement module included in NIS software (Fig. 7B).

A minimum event detection threshold of $2 \mu \mathrm{m}^{3}$ was chosen according to the average volume of intracytoplasmic labelling ( 2 to $50 \mu \mathrm{m}^{3}$ per cell) previously detected by confocal microscopy and to the mean volume of false-positive events detected in the control liver $\left(0.20 \mu \mathrm{m}^{3} \pm 0.29\right)$. As a result, 148 far-red emitting events have been detected in the whole volume analysed of the positive liver, with a mean volume of $49 \mu^{3}( \pm 134)$ with some objects reaching up to $1500 \mathrm{\mu m}^{3}$, suggesting concentration of several labelled cells. Distribution analyses demonstrated a homogenous repartition of the events in the 8 liver volumes independently analysed (mean events per volume $=9 \pm 3$, Fig. 7C) and also a homogenous repartition of the events in depth (Q1:278.9 $\mu$ m, median: $451.9 \mu \mathrm{m}, \mathrm{Q} 3: 694.7 \mu \mathrm{m}$-Fig. 7D) thus eliminating a potential detection defect correlated to the imaging depth. 

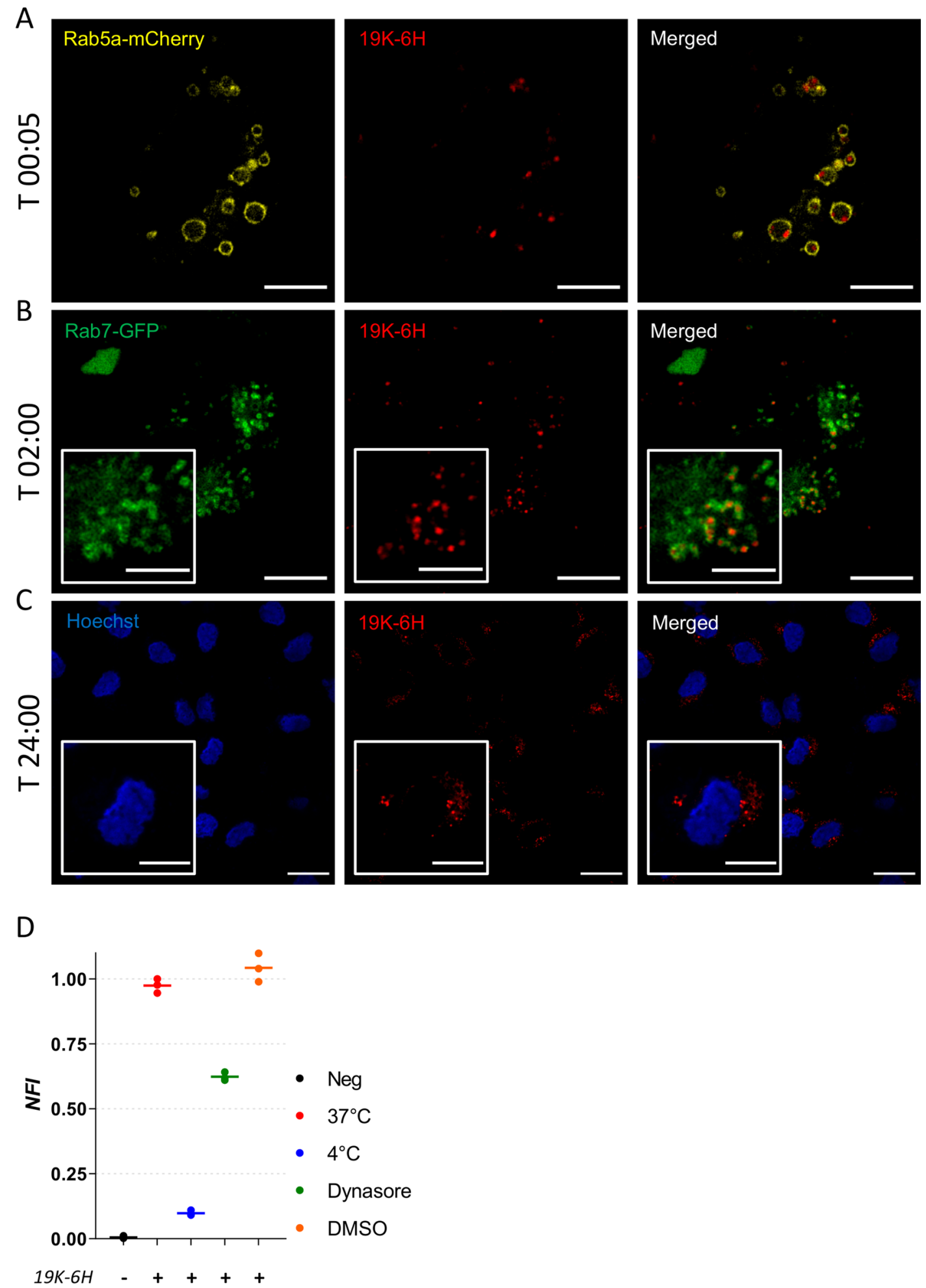

Figure 4. Confocal microscopy of living Hela cells incubated with $19 \mathrm{~K}-6 \mathrm{H}$ probe and transfected with plasmid coding for endosomal markers fused with fluorescent proteins (Rab7-GFP, Rab5a-mCherry) or labelled with nuclear counterstain (Hoechst) (objective $\times 63$ ). (A) HeLa cell transfected with Rab5a-mCherry plasmid, after $5 \mathrm{~min}$ incubation of $19 \mathrm{~K}-6 \mathrm{H}$ probe $(10 \mu \mathrm{M})$. Excitation $561 \mathrm{~nm}$. Representative of 3 experiments. Scale bar: 10 $\mu \mathrm{m}$. (B) HeLa cell transfected with Rab7-GFP plasmid, after $2 \mathrm{~h}$ incubation of $19 \mathrm{~K}-6 \mathrm{H}$ probe $(10 \mu \mathrm{M})$. Dual sequential excitation $488 \mathrm{~nm}$ and $561 \mathrm{~nm}$. Representative of 3 experiments. Scale bar: $10 \mu \mathrm{m}$. ROI close up, scale bar: $5 \mu \mathrm{m}$. (C) HeLa cells labelled with Hoechst 33342, after $24 \mathrm{~h}$ incubation of 19K-6H probe $(10 \mu \mathrm{M})$. Excitation $405 \mathrm{~nm}$ and $561 \mathrm{~nm}$. Scale bar: $20 \mu \mathrm{m}$. ROI close-up, scale bar: $10 \mu \mathrm{m}$. Fluorescent images (visualized in blue, red, green and yellow: false colors) are presented separately on left and middle panel and merged on right panel. (D) HeLa cells are incubated $8 \mathrm{~h}$ with $19 \mathrm{~K}-6 \mathrm{H}$ probe $(10 \mu \mathrm{M})$ at $37^{\circ} \mathrm{C}$ or $4{ }^{\circ} \mathrm{C}$ or in presence of $80 \mu \mathrm{M}$ of Dynasore $\left(37^{\circ} \mathrm{C}\right.$ ) or DMSO (Dynasore Solvent $-37^{\circ} \mathrm{C}$ ) in the culture medium. $19 \mathrm{~K}-6 \mathrm{H}$ labelling is evaluated by FACS. NFI: normalized fluorescence intensity. $\mathrm{n}=3$. Bar: median values. 
A

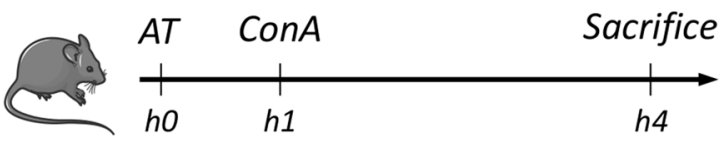

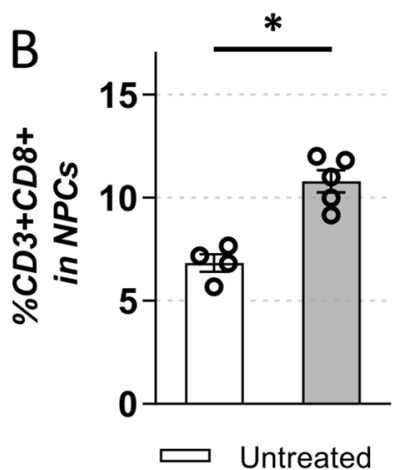

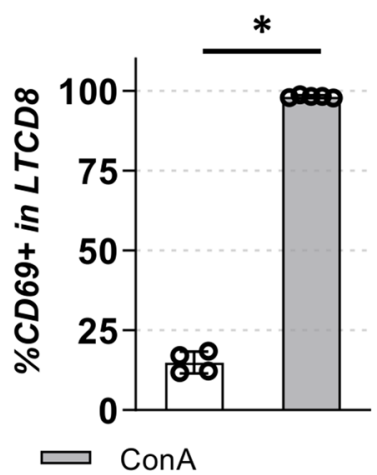

$\mathrm{D}$
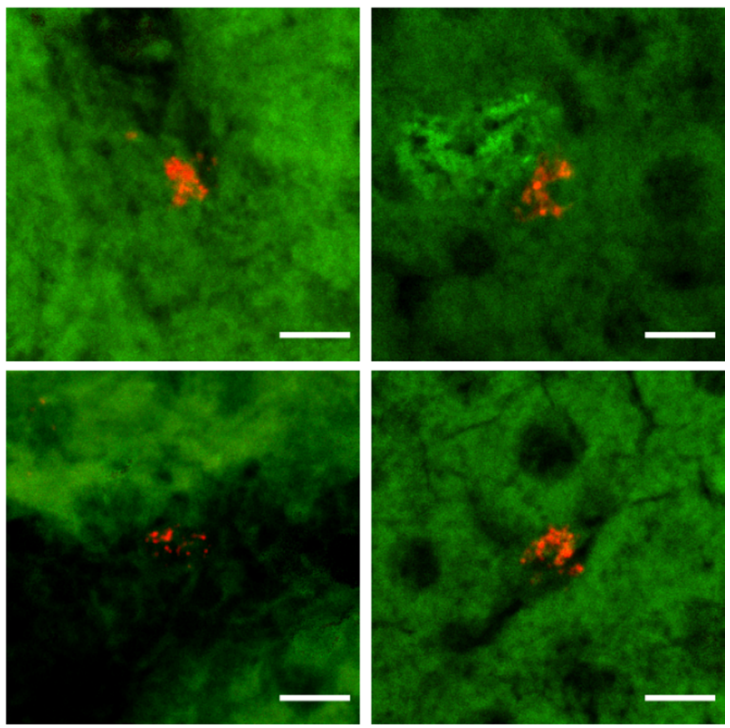

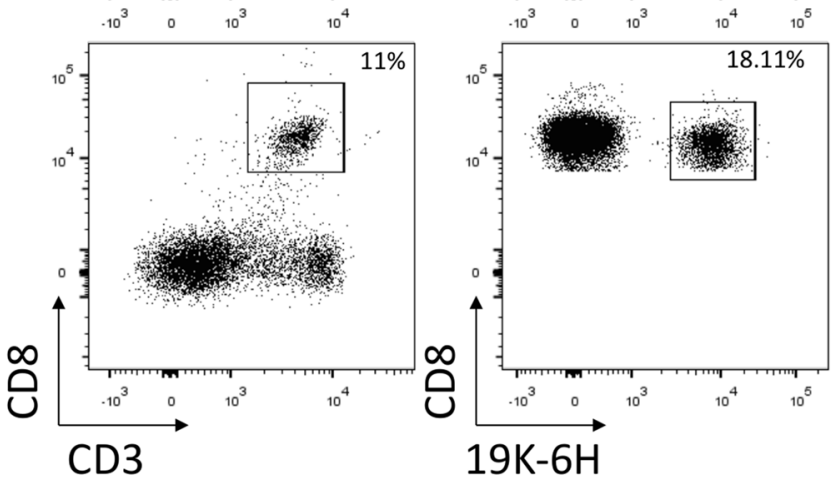

Figure 5. Adoptive transfer of pCD $8 \mathrm{~T}$ cells (harvested the day before on $\mathrm{C} 57 \mathrm{Bl} / 6$ mice, cultured $\mathrm{O} / \mathrm{N}$ with activation signals) labelled or not with $19 \mathrm{~K}-6 \mathrm{H}$. (A) Mice are injected with $15 \mathrm{mg} / \mathrm{kg}$ Concanavalin A (ConA) or PBS $1 \mathrm{~h}$ after adoptive transfer $(A T)$, then sacrificed $3 \mathrm{~h}$ later. Liver are collected for (B) FACS analysis (CD3, CD8, CD69) of the recruitment of CD8 T cells (left panel) and their activation state (right panel) after ConA injection (significance is calculated by Mann-Whitney test. $\left.{ }^{*} \mathrm{p}<0.05\right),(\mathrm{C})$ FACS analysis (CD3, CD8, 19K-6H) of ConA treated mice, top panels: ctrl pCD8 T cells injected, bottom panels: 19K-6H-labelled pCD8 T cells injected and (D) confocal spectral microscopy analysis (objective $\times 20$, scale bar $10 \mu \mathrm{m}$ ) on liver cryosections (thickness $15 \mu \mathrm{m}$ ) of 19K-6H-labeled pCD8 T cells/ConA injected mice. Excitation wavelengths were both $488 \mathrm{~nm}$ and $561 \mathrm{~nm}$ with 500-690 nm emission wavelength range (spectral imaging with $8.9 \mathrm{~nm}$ spectral band). Fluorescent images of 4 positives events are presented (false colors, green: liver background, red : $19 \mathrm{~K}-6 \mathrm{H}$ positive events).

\section{Discussion}

The development and optimization of primary cell tracking in animal models is of major importance in the field of cell therapy in order to better assess the engraftment properties, behaviour and localization of the injected cells. For this purpose, non-invasive strategies consisting in the ex vivo labelling of the cells with fluorescent probes before their injection has been developed in the last decade, as an alternative to genetic modifications, for instance ${ }^{5,6}$. The most important criteria for those probes are the biocompatibility (to preserve cell integrity and functionality, especially in the case of primary cells that are significantly more fragile than cell lines), the emitted fluorescence (intensity, stability, wavelengths, easy discrimination from tissue autofluorescence ${ }^{8-10}$ ) and the versatility for implementing multiscale technical approaches like microscopy and flow cytometry. In this regard, the development of fluorescent probes suitable for both confocal and TPEF-microscopy is of particular interest for deep imaging ${ }^{11,12}$. One of the challenging issues is to develop far-red emitting probes, highly discriminative from liver autofluorescence, exhibiting a large Stokes shift as well as high 2P-absorption and presenting biocompatibility properties at concentrations enabling a convenient imaging.

Water-soluble polymer probes bearing $2 \mathrm{P}$-absorbing fluorophores emitting in the far-red range are excellent candidates. Previous results showed a low cytotoxicity on various cell lines ${ }^{30}$, with an efficient labelling of enveloped viruses $^{29}$, living cells and zebrafish embryos enabling their visualization by TPEF-microscopy ${ }^{30}$. In 
A

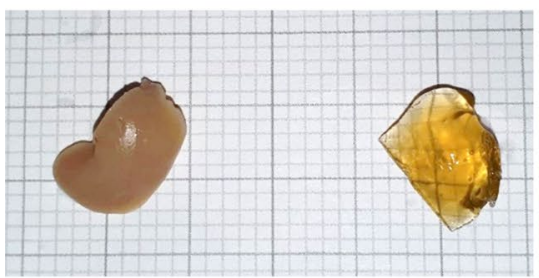

B
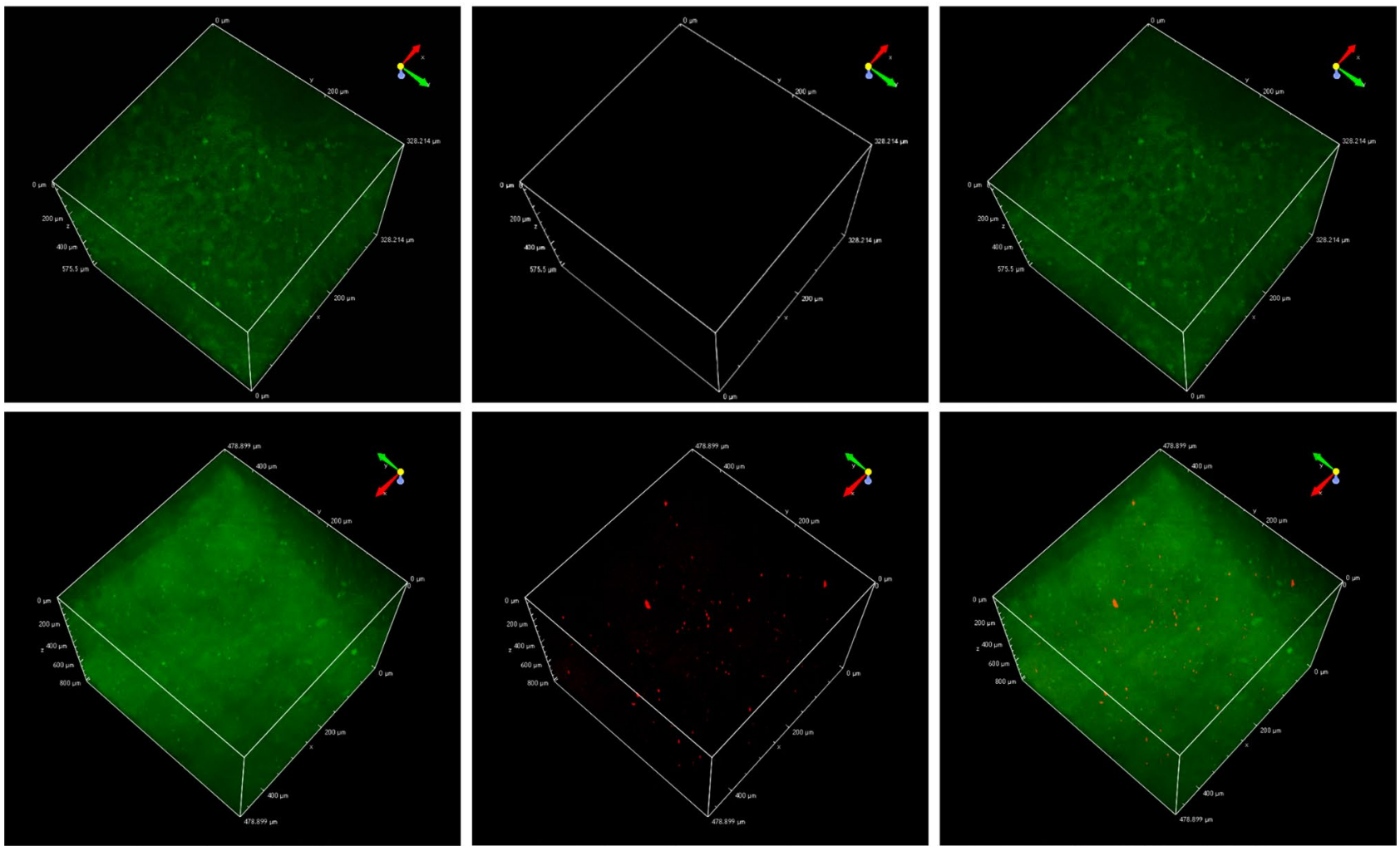

Figure 6. (A) Clearing of liver $800 \mu \mathrm{m}$ sections thanks to CUBIC protocol. Left: before clearing; right : after clearing. (B) TPEF-microscopy analysis (objective $\times 25$ ) on cleared liver $800 \mu \mathrm{m}$ sections of $19 \mathrm{~K}-6 \mathrm{H}$-labelled (bottom panel-x: $478.9 \mu \mathrm{m}, \mathrm{y}: 478.9 \mu \mathrm{m}, \mathrm{z}: 800 \mu \mathrm{m}$ ) or control (top panel-x: $328.14 \mu \mathrm{m}, \mathrm{y}: 328.14 \mu \mathrm{m}, \mathrm{z}: 575.5$ $\mu \mathrm{m})$ pCD8 T cells injected mice. Dual wavelength excitation. From $\lambda_{\mathrm{ex}} 900 \mathrm{~nm}$, autofluorescence was collected in green channel (500-550 nm). From $\lambda_{\text {ex }} 1040 \mathrm{~nm}, 19 \mathrm{~K}-6 \mathrm{H}$ fluorescence was collected in far-red channel (601-657 nm). Fluorescent images (visualized in green and red, false colors) are presented separately on left and middle panel and merged on right panel.

this article, we investigated the benefits of the new $19 \mathrm{~K}-6 \mathrm{H}$ far-red emitting polymer probe (Fig. 1A) for the tracking of primary immune CD8 T cells (pCD8 T cells) in a mouse model of liver infiltration through multiscale approaches including both confocal and TPEF-microscopy as well as flow cytometry for high-throughput cell analysis.

First, we demonstrated that pCD8 T cells were efficiently labelled with 5 to $20 \mu \mathrm{M}$ of $19 \mathrm{~K}-6 \mathrm{H}$ after 15 -h incubation, resulting in an intracytoplasmic staining with vesicular spots of high intensity. The labelling was easily detected by confocal microscopy with 488 and $561 \mathrm{~nm}$ laser excitation wavelengths, and emission peaks exhibiting a maximum at 650 and $660 \mathrm{~nm}$, respectively, have been determined with the spectral module. This result confirms previous observations and the large Stokes shift associated with the far-red emitting fluorophore covalently bound on the $19 \mathrm{~K}-6 \mathrm{H}$ probe ${ }^{27}$. This large Stokes shift (around $180 \mathrm{~nm}$, see Figure S2) enables minimization of the self-quenching effect and leads to an enhanced signal-to-noise ratio ${ }^{41}$. This represents a major advantage compared to most of the commercially available far-red emitting fluorophores; for instance: borondipyrromethene (BODIPY) ${ }^{42,43}$, cyanine or rhodamine dyes ${ }^{44,45}$, that display Stokes shifts limited to $\sim 20 \mathrm{~nm}$.

In addition, $19 \mathrm{~K}-6 \mathrm{H}$ labelled-pCD8 $\mathrm{T}$ cells were optimally visualized under a $2 \mathrm{P}$-excitation at $1040 \mathrm{~nm}$, which is a very convenient wavelength in the range of standard femto-second pulse laser of common TPEFmicroscopes. In a previous article ${ }^{30}$, after labelling HeLa cell lines with a related polymer probe bearing the same fluorophore, we determined a maximum 2P-excitation wavelength at $920 \mathrm{~nm}$. However, in that experiment, the 


\section{B}

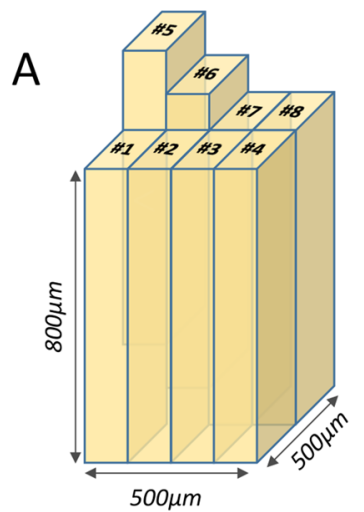

C

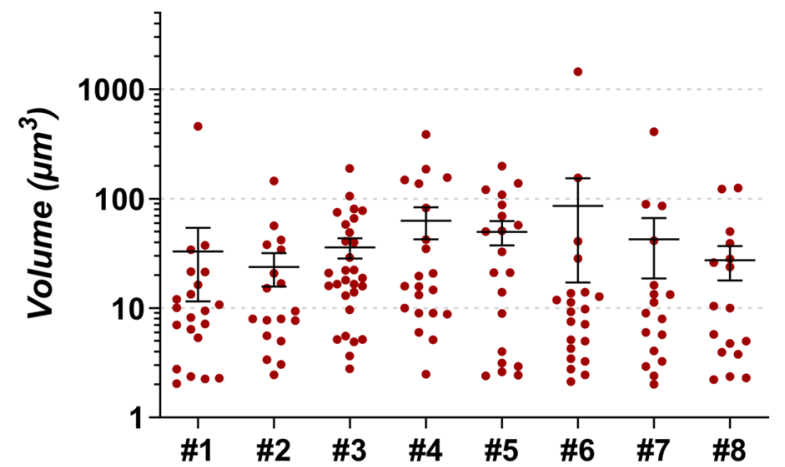

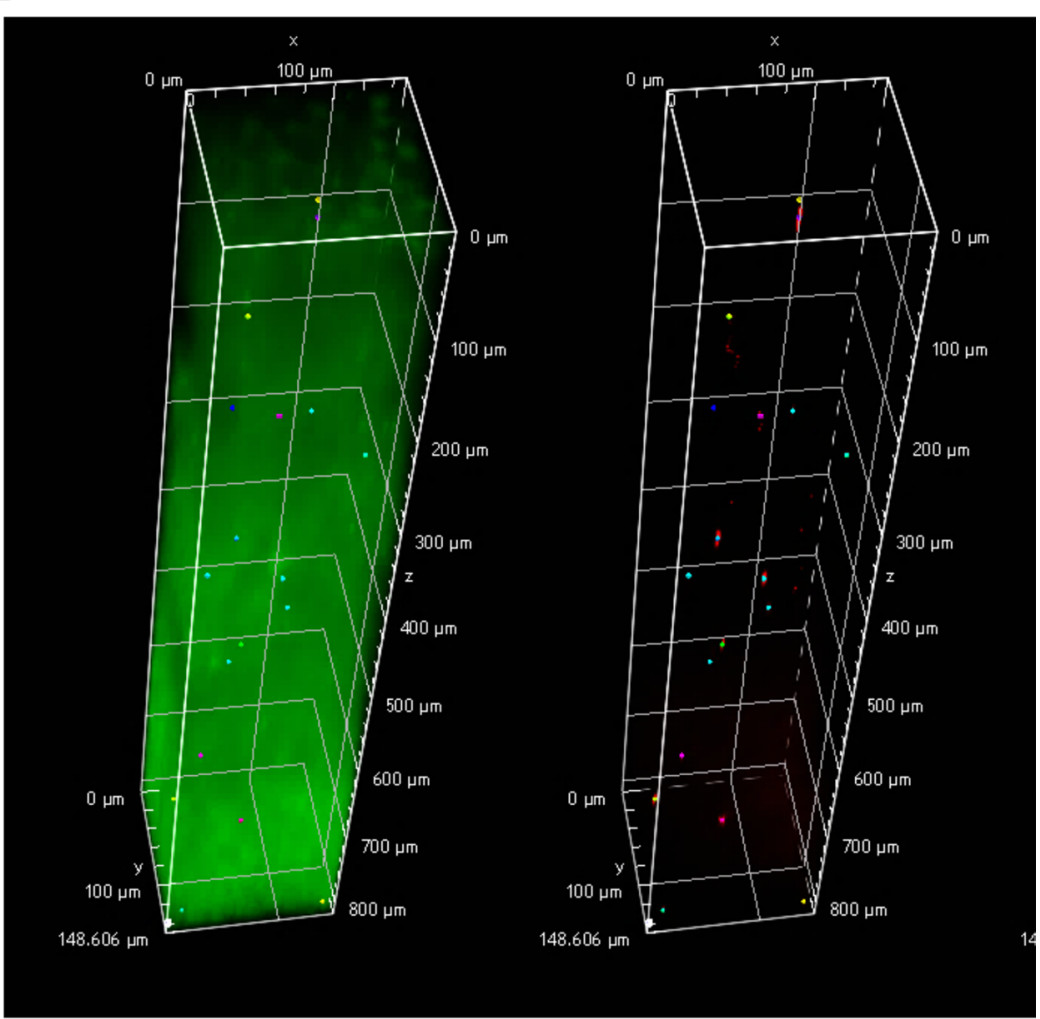

D

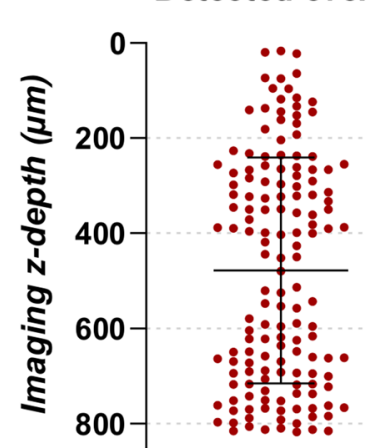

Figure 7. (A) $0.186 \mathrm{~mm}^{3}(\sim 500 * 500 * 800 \mu \mathrm{m})$ of the liver of mice injected with labelled pCD8 T cells was investigated through 8 independent and non-overlapping analyses (\#1 to \#8) of $0.0232 \mathrm{~mm}^{3}$ with the (B) 3D measurement module included in NIS software. (C) Distribution of the far-red emitting events in the 8 independently analyzed liver volumes. Bars represent the mean and the standard-error calculated for each volume. (D) Distribution of the far-red emitting events in $\mathrm{z}$-depth imaged in liver volume. Bars represent the mean and the standard-deviation.

2P-excitation spectrum could only be reconstructed up to $1000 \mathrm{~nm}$ due to the laser range limitation. Therefore, we may deduce that $1040 \mathrm{~nm}$ is the main maximum $2 \mathrm{P}$-absorption wavelength of this polymer probe in cellulo and that $920 \mathrm{~nm}$ is a secondary maximum. It is worth mentioning that a $2 \mathrm{P}$-absorption spectrum in water of an oligomer probe based on the same fluorophore indicated a maximum 2P-absorption wavelength around $1050 \mathrm{~nm}$ and a secondary maximum around $950-980 \mathrm{~nm}^{28}$.

We then investigated the stability of the $19 \mathrm{~K}-6 \mathrm{H}$ labelling, in terms of fluorescence intensity and emission spectra, on murine pCD8 T cells and showed that the labelling was still detectable (by both confocal microscopy and flow cytometry) after 3 days of proliferation for the concentrations $5 \mu \mathrm{M}$ and $20 \mu \mathrm{M}$. The fluorescence decrease, observed proportionally to the cell proliferation, argues for a fair partitioning of the $19 \mathrm{~K}-6 \mathrm{H}$ probe during cell division, which is of importance considering the in vivo applications and the potential proliferation of the cells in the host. Furthermore, emission spectra were identical over time (Fig. 2D), indicating that the probes globally remained in the same local environment without degradation. 
The working concentrations to obtain an adequate labelling for our application ( 5 to $20 \mu \mathrm{M}$ ) are higher than those reported for HeLa and Jurkat cells with a previous generation of far-red emitting polymer probes $(0.2$ to $1 \mu \mathrm{M})^{30}$. This could reflect the difference of brightness of those probes measured in water: $13100 \mathrm{~cm}^{-1} \mathrm{~mol}^{-1} \mathrm{~L}$ for the previous one $\mathrm{e}^{30}$ and $2800 \mathrm{~cm}^{-1} \mathrm{~mol}^{-1} \mathrm{~L}$ for the present one. It could also be due to the intrinsically limited internalization process of primary cells compared to metabolically over-active tumoral cell lines. Indeed, when labelled simultaneously in the same conditions ( $5 \mu \mathrm{M} 19 \mathrm{~K}-6 \mathrm{H}, 15-\mathrm{h}$ incubation), Jurkat cells showed a 4-time brighter labelling than primary CD8 T cells (data not shown). Similar results have been described on HTB-125 (human epithelial non-cancerous cell) and HTB-126 (human epithelial cancerous cell) labelled with a lipidderived fluorescent probe internalized through endocytosis ${ }^{46}$.

Primary cells present a high biological heterogeneity compared to established cell lines, more representative of their in vivo, physiological origin. It is thus necessary to study the potential cytotoxicity of the probe on the primary cells prior to develop in vivo cell tracking for cell therapy applications. In line with the innocuity of similar far-red emitting polymer probes previously shown on Jurkat cells ${ }^{30}$, we demonstrated in the present study that the $19 \mathrm{~K}-6 \mathrm{H}$ probe did not induce direct cytotoxicity on primary CD8 T cells after a 15-h incubation even at the highest concentration $(20 \mu \mathrm{M})$ (Fig. 3A). Such biocompatibility was further confirmed by the absence of long-term cytotoxicity, as neither the proliferation nor the activation of PCD8 T cells in response to mitogenic factors were altered (Fig. 3A). Thus, whereas the biocompatibility of many fluorescent nanoparticles remains to be thoroughly investigated ${ }^{47}$, we demonstrated here that the $19 \mathrm{~K}-6 \mathrm{H}$ polymer probe labelling did not alter the function of the primary $\mathrm{T}$ cells.

Given the observed heterogeneous subcellular distribution of the $19 \mathrm{~K}-6 \mathrm{H}$ probe in highly fluorescent spots which suggested a preferential localization in intracellular vesicles, we investigated the endocytosis-mediated internalization pathways with a previously described model of engineered HeLa cells ${ }^{36,37}$. The $19 \mathrm{~K}-6 \mathrm{H}$ was found successively in early endosomes (Rab5A-mCherry, very first minutes after incubation) then in late endosomes (Rab7-GFP, $2 \mathrm{~h}$ ) in a timely manner. Moreover, internalization was inhibited at $4{ }^{\circ} \mathrm{C}$, a temperature that does not allow for endocytosis ${ }^{48}$. The partial internalization inhibition observed with Dynasore, a dynamin inhibitor ${ }^{38}$, suggested that the $19 \mathrm{~K}-6 \mathrm{H}$ probe could take several endocytic pathways including dynamin-dependent and -independent pathways ${ }^{49,50}$. Therefore, the distribution of the probe during cell division could be linked to the stochastic endosome inheritance occurring during mitosis in mammalian cell lines ${ }^{51,52}$. As a perspective, it could be interesting to further investigate the fate of the probe in the cell, along the lysosomal and recycling endosomes pathways ${ }^{53}$.

Finally, we investigated the potential of the $19 \mathrm{~K}-6 \mathrm{H}$ probe for the tracking of primary immune CD8 T cells in a mouse model of liver leukocyte infiltration. The development of a versatile fluorescent probe that can enable the use of several techniques within a single experiment, to bring complementary information is of high interest. In addition, this is also worthy on an ethical point of view, as it limits the number of animals for in vivo studies. Among the most informative techniques, the flow cytometry analysis enables a detailed high-throughput phenotyping of immune cells collected from an organ (such as the liver). Deep imaging with TPEF-microscopy brings the $3 \mathrm{D}$ localisation information which is lost in the tissue dissociation step necessary for flow cytometry analysis. We demonstrated here that the $19 \mathrm{~K}-6 \mathrm{H}$ probe is very versatile as it can be used in the same experiment for both imaging of extemporaneously-labelled immune cells (from confocal microscopy to TPEF-microscopy for deep imaging) and flow cytometry. We used a well-designed mouse model of T cell-induced liver injury in response to Concanavalin A injection ${ }^{39}$. In this model, the injected $19 \mathrm{~K}-6 \mathrm{H}$ labelled pCD8 T cells were easily detectable within the total NPC by flow cytometry but were seldom imaged by confocal spectral microscopy on 15 $\mu \mathrm{m}$ frozen liver sections. The $19 \mathrm{~K}-6 \mathrm{H}$-labelled pCD8 $\mathrm{T}$ cells could be imaged in vivo by TPEF-microscopy under $1040 \mathrm{~nm}$ excitation, the optimal 2P-absorption of the 19K-6H probe. With biological samples, TPEF-microscopy enables imaging on a maximal depth of 300 to $500 \mu \mathrm{m}$ depending on the tissue ${ }^{12,54}$. To gain insight into the 3D localization of the labelled CD8 T cells within the liver, we associated TPEF-microscopy with a clearing protocol. The clearing protocol, applied as pre-treatment of the thick liver sections, increased imaging depth, and thus the probability of imaging relatively rare events. We used the CUBIC-protocol ${ }^{16,35,40}$ based on successive steps of delipidation, decolorization and refractive index matching, that allows deeper imaging (up to $4 \mathrm{~mm}$ ) by lowering light scattering by the tissues. Moreover, this aqueous-based clearing protocol is supposed to be less toxic than organic ones and to improve fluorescence preservation ${ }^{16}$. TPEF-imaging could then be performed on 800 $\mu \mathrm{m}$ thick liver sections. 19K-6H-labelled pCD8 T cells appeared with a high signal-to-noise ratio in the far-red channel. This strong signal was highly specific, easily discriminated from the hepatic autofluorescence observed in the green channel. Indeed, by using adequate acquisition parameters and a fixed minimum threshold volume of $2 \mu \mathrm{m}^{3}, 148$ far-red emitting events have been detected in the analysed liver sample $\left(0.186 \mathrm{~mm}^{3}\right)$ of mice injected with labelled pCD8 T cells whereas none were detected in the control liver (injected with unlabelled pCD8 T cells). Those events displayed a mean volume of $49 \mu \mathrm{m}^{3}$ which is in line with the average size of pCD8 T cells (3-5 $\mu \mathrm{m}$, Figs. 1B,D, 2B, S3, S4). The density of fluorescent events was quantified to 796 events $/ \mathrm{mm}^{3}$, and it can be extrapolated to approximately $1.3 \times 10^{6} 19 \mathrm{~K}-6 \mathrm{H}$-labelled pCD8 T cells for a whole liver $\left(1650 \mathrm{~mm}^{355}\right)$. This range is consistent with the number of $19 \mathrm{~K}-6 \mathrm{H}$-labelled cells injected to the mice $\left(1.5 \times 10^{7}\right.$ cells $)$. In addition, the global homogenous distribution of the cells (Fig. 7B,C) with some events reaching up to $1500 \mu^{3}$ (considered as cell clusters) match to the mouse model of T cell-mediated acute liver hepatitis induced by the Concanavalin $\mathrm{A}^{39}$.

In conclusion, we demonstrated in the present article that the new $19 \mathrm{~K}-6 \mathrm{H}$ polymer probe is a highlybiocompatible and versatile probe with a bright and stable fluorescence adapted for multiscale and complementary approaches such as flow cytometry, for high-throughput cell analysis, and fluorescence microscopy (including TPEF-microscopy) for subcellular information and localization of the cells in the analysed organ. Moreover, we showed that the $19 \mathrm{~K}-6 \mathrm{H}$ is a robust tool, resistant to acetone- and PFA-fixation as well as CUBICclearing, thus making it even more versatile and multiplying its potential fields of applications. Finally, given the high $2 \mathrm{P}$-absorption of the $19 \mathrm{~K}-6 \mathrm{H}$ probe at $1040 \mathrm{~nm}$, another interesting application to investigate will be the 
intra-vital in vivo two-photon scanning laser microscopy by using dual wavelength excitation $(1040 / 900 \mathrm{~nm})$ to provide dynamic insights of cell behaviours in a real-time manner ${ }^{14,15}$.

Received: 6 July 2020; Accepted: 5 October 2020

Published online: 16 October 2020

\section{References}

1. Gill, S., Maus, M. V. \& Porter, D. L. Chimeric antigen receptor T cell therapy: 25 years in the making. Blood Rev. 30, 157-167 (2016).

2. Edozie, F. C. et al. Regulatory T-cell therapy in the induction of transplant tolerance: The issue of subpopulations. Transplantation 98, 370-379 (2014).

3. Lee, K., Nguyen, V., Lee, K.-M., Kang, S.-M. \& Tang, Q. Attenuation of donor-reactive T cells allows effective control of allograft rejection using regulatory T cell therapy: Prerequisite for Treg control of alloimmunity. Am. J. Transplant. 14, 27-38 (2014).

4. Seth, A., Park, H. \& Hong, K. Current perspective on in vivo molecular imaging of immune cells. Molecules 22, 881 (2017).

5. Kiessling, F. Noninvasive cell tracking. In Molecular Imaging II Vol. 185/2 (eds Semmler, W. \& Schwaiger, M.) 305-321 (Springer, Berlin, 2008).

6. Progatzky, F., Dallman, M. J. \& Lo Celso, C. From seeing to believing: Labelling strategies for in vivo cell-tracking experiments. Interface Focus 3, 20130001 (2013).

7. Sanderson, M. J., Smith, I., Parker, I. \& Bootman, M. D. Fluorescence microscopy. Cold Spring Harb. Protoc. 2014, pdb.top071795 (2014).

8. Swenson, E. S., Price, J. G., Brazelton, T. \& Krause, D. S. Limitations of green fluorescent protein as a cell lineage marker. Stem Cells 25, 2593-2600 (2007).

9. Monici, M. Cell and tissue autofluorescence research and diagnostic applications. In Biotechnology Annual Review, Vol. 11, 227-256 (Elsevier, Amsterdam, 2005).

10. Jun, Y. W., Kim, H. R., Reo, Y. J., Dai, M. \& Ahn, K. H. Addressing the autofluorescence issue in deep tissue imaging by two-photon microscopy: The significance of far-red emitting dyes. Chem. Sci. 8, 7696-7704 (2017).

11. Zipfel, W. R., Williams, R. M. \& Webb, W. W. Nonlinear magic: Multiphoton microscopy in the biosciences. Nat. Biotechnol. 21, 1369-1377 (2003).

12. Helmchen, F. \& Denk, W. Deep tissue two-photon microscopy. Nat. Methods 2, 932-940 (2005).

13. Centonze, V. E. \& White, J. G. Multiphoton excitation provides optical sections from deeper within scattering specimens than confocal imaging. Biophys. J. 75, 2015-2024 (1998).

14. Pittet, M. J. \& Weissleder, R. Intravital imaging. Cell 147, 983-991 (2011).

15. Guidotti, L. G. et al. Immunosurveillance of the liver by intravascular effector CD8+ T cells. Cell 161, 486-500 (2015).

16. Costantini, I., Cicchi, R., Silvestri, L., Vanzi, F. \& Pavone, F. S. In-vivo and ex-vivo optical clearing methods for biological tissues: Review. Biomed. Opt. Express 10,5251 (2019).

17. Bhirde, A., Xie, J., Swierczewska, M. \& Chen, X. Nanoparticles for cell labeling. Nanoscale 3, 142-153 (2011).

18. Noh, Y.-W., Lim, Y. T. \& Chung, B. H. Noninvasive imaging of dendritic cell migration into lymph nodes using near-infrared fluorescent semiconductor nanocrystals. FASEB J. 22, 3908-3918 (2008).

19. Derfus, A. M., Chan, W. C. W. \& Bhatia, S. N. Probing the cytotoxicity of semiconductor quantum dots. Nano Lett. 4, 11-18 (2004).

20. Chen, N. et al. The cytotoxicity of cadmium-based quantum dots. Biomaterials 33, 1238-1244 (2012).

21. Lim, M. et al. Synthesis of far-red- and near-infrared-emitting Cu-doped InP/ZnS (core/shell) quantum dots with controlled doping steps and their surface functionalization for bioconjugation. Nanoscale 11, 10463-10471 (2019).

22. Massey, M., Wu, M., Conroy, E. M. \& Algar, W. R. Mind your P's and Q's: The coming of age of semiconducting polymer dots and semiconductor quantum dots in biological applications. Curr. Opin. Biotechnol. 34, 30-40 (2015).

23. Wu, C. et al. Design of highly emissive polymer dot bioconjugates for in vivo tumor targeting. Angew. Chem. Int. Ed. 50, 3430-3434 (2011).

24. Hassan, A. M. et al. Polymer dots enable deep in vivo multiphoton fluorescence imaging of microvasculature. Biomed. Opt. Express 10, 584 (2019).

25. Dubreil, L. et al. Multi-harmonic imaging in the second near-infrared window of nanoparticle-labeled stem cells as a monitoring tool in tissue depth. ACS Nano 11, 6672-6681 (2017).

26. Adjili, S. et al. Synthesis of multifunctional lipid-polymer conjugates: Application to the elaboration of bright far-red fluorescent lipid probes. RSC Adv. 4, 15569-15578 (2014).

27. Massin, J. et al. Near-infrared solid-state emitters based on isophorone: Synthesis, crystal structure and spectroscopic properties. Chem. Mater. 23, 862-873 (2011).

28. Massin, J. et al. A water soluble probe with near infrared two-photon absorption and polarity-induced fluorescence for cerebral vascular imaging. Chem. Sci. 4, 2833 (2013).

29. Lacour, W. et al. Far-red fluorescent lipid-polymer probes for an efficient labeling of enveloped viruses. Adv. Healthc. Mater. 5, 2032-2044 (2016).

30. Adjili, S. et al. Biocompatible photoresistant far-red emitting, fluorescent polymer probes, with near-infrared two-photon absorption, for living cell and zebrafish embryo imaging. Biomaterials 46, 70-81 (2015).

31. Chamignon, C., Duret, D., Charreyre, M.-T. \& Favier, A. ${ }^{1}$ H DOSY NMR determination of the molecular weight and the solution properties of poly( $\mathrm{N}$-acryloylmorpholine) in various solvents. Macromol. Chem. Phys. 217, 2286-2293 (2016).

32. Favier, A., D’Agosto, F., Charreyre, M.-T. \& Pichot, C. Synthesis of $N$-acryloxysuccinimide copolymers by RAFT polymerization, as reactive building blocks with full control of composition and molecular weights. Polymer 45, 7821-7830 (2004).

33. Cepraga, C. et al. Biocompatible well-defined chromophore-polymer conjugates for photodynamic therapy and two-photon imaging. Polym. Chem. 4, 61-67 (2013).

34. Le Guen, V. et al. Alloantigen gene transfer to hepatocytes promotes tolerance to pancreatic islet graft by inducing CD8+ regulatory T cells. J. Hepatol. 66, 765-777 (2017).

35. Tainaka, K. et al. Chemical landscape for tissue clearing based on hydrophilic reagents. Cell Rep. 24, 2196-2210.e9 (2018).

36. Bohdanowicz, M., Balkin, D. M., De Camilli, P. \& Grinstein, S. Recruitment of OCRL and Inpp5B to phagosomes by Rab5 and APPL1 depletes phosphoinositides and attenuates Akt signaling. Mol. Biol. Cell 23, 176-187 (2012).

37. Rojas, R. et al. Regulation of retromer recruitment to endosomes by sequential action of Rab5 and Rab7. J. Cell Biol. 183, 513-526 (2008).

38. Kirchhausen, T., Macia, E. \& Pelish, H. E. Use of dynasore, the small molecule inhibitor of dynamin, in the regulation of endocytosis. In Methods in Enzymology, Vol. 438, 77-93 (Elsevier, Amsterdam, 2008).

39. Tiegs, G., Hentschel, J. \& Wendel, A. A T cell-dependent experimental liver injury in mice inducible by concanavalin A. J. Clin. Investig. 90, 196-203 (1992).

40. Susaki, E. A. et al. Advanced CUBIC protocols for whole-brain and whole-body clearing and imaging. Nat. Protoc. 10, 1709-1727 (2015). 
41. Albrecht, C. \& Joseph, R. Lakowicz: Principles of fluorescence spectroscopy, 3rd edition. Anal. Bioanal. Chem. 390, 1223-1224 (2008).

42. Bardon, K. M. et al. Synthesis of water-soluble far-red-emitting amphiphilic BODIPY dyes. ACS Omega 3, 13195-13199 (2018).

43. Loudet, A. \& Burgess, K. BODIPY dyes and their derivatives: Syntheses and spectroscopic properties. Chem. Rev. 107, 4891-4932 (2007).

44. Beija, M., Afonso, C. A. M. \& Martinho, J. M. G. Synthesis and applications of rhodamine derivatives as fluorescent probes. Chem. Soc. Rev. 38, 2410 (2009).

45. Wiederschain, G. Y. The molecular probes handbook. A guide to fluorescent probes and labeling technologies: (I. Johnson and M. Spence (eds.) 11th Edition, Life Technologies, 2010, 1060 p., \$100). Biochem. Mosc. 76, 1276-1276 (2011).

46. Levine, M. N., Hoang, T. T. \& Raines, R. T. Fluorogenic probe for constitutive cellular endocytosis. Chem. Biol. 20, 614-618 (2013).

47. Nel, A. \& Xia, T. Toxic potential of materials at the nanolevel. Science 311, 7 (2006).

48. Tomoda, H. \& Kishimoto, Y. Temperature effect on endocytosis and exocytosis by rabbit alveolar macrophages. J. Biol. Chem. 264(26), 15445-15450 (1989).

49. Mayor, S., Parton, R. G. \& Donaldson, J. G. Clathrin-independent pathways of endocytosis. Cold Spring Harb. Perspect. Biol. 6, a016758-a016758 (2014).

50. Doherty, G. J. \& McMahon, H. T. Mechanisms of endocytosis. Annu. Rev. Biochem. 78, 857-902 (2009).

51. Bergeland, T., Widerberg, J., Bakke, O. \& Nordeng, T. W. Mitotic partitioning of endosomes and lysosomes. Curr. Biol. 11, 644-651 (2001).

52. Dunster, K. Early endosomes, late endosomes, and lysosomes display distinct partitioning strategies of inheritance with similarities to Golgi-derived membranes. Eur. J. Cell Biol. 81, 117-124 (2002).

53. Goldenring, J. R. Recycling endosomes. Curr. Opin. Cell Biol. 35, 117-122 (2015).

54. Rubart, M. Two-photon microscopy of cells and tissue. Circ. Res. 95, 1154-1166 (2004).

55. Hall, C., Lueshen, E., Mošat, A. \& Linninger, A. A. Interspecies scaling in pharmacokinetics: A novel whole-body physiologically based modeling framework to discover drug biodistribution mechanisms in vivo. J. Pharm. Sci. 101, 1221-1241 (2012).

\section{Acknowledgements}

This manuscript is a tribute to the 50 year anniversary of the French Polymer Group (Groupe Français des Polymères-GFP). We wish to thank the UTE IRS-UN animal facility of the SFR Santé F. Bonamy (Université de Nantes, INSERM UMS016, CNRS UMS3556). We acknowledge Dr. Julien Massin, Dr. Yann Bretonnière and Dr. Chantal Andraud (Laboratoire de Chimie, ENS de Lyon) for the isophorone derivative fluorophore and for the use of their spectrophotometer and spectrofluorimeter equipments. We acknowledge Dr. Salim Adjili and Laura Possi-Tchouanlong (Laboratoire IMP) for, respectively, some help to TB for the synthesis/characterization of the polymer probe and the determination of its molar extinction coefficient and fluorescence quantum yield. We acknowledge APEX platform of the INRA/Oniris UMR 703 PAnTher, Center of Excellence Nikon Nantes (Nantes, France).

\section{Author contributions}

M.D. performed the experiments, analysed the results and wrote the manuscript. L.D., R.F. performed microscopy studies and analyses. J.-P.J. participated to animal experiments. T.B., A.F. and M-T.C. produced and provided the $19 \mathrm{~K}-6 \mathrm{H}$ probe. S.C., S.B. provided funding. S.C., S.B., M-T.C., A.F., L.D. participated to the redaction of the manuscript. S.C., M.-T.C. and L.D. supervised this interdisciplinary project in conception and execution.

\section{Funding}

This work was supported by institutional grants from INSERM and Université de Nantes to the Centre de Recherche en Transplantation et Immunologie. The project was funded by grants from AFM Telethon (\#20791, \#21337). It was carried out in the context of the IHU-Cesti project (ANR-10-IBHU-005) and of the LabEX IGO program (ANR-11-LABX-0016-01). The IHU-Cesti project was also supported by Nantes Métropole and the Région Pays de la Loire.

\section{Competing interests}

The authors declare no competing interests.

\section{Additional information}

Supplementary information is available for this paper at https://doi.org/10.1038/s41598-020-74621-9.

Correspondence and requests for materials should be addressed to S.C.

Reprints and permissions information is available at www.nature.com/reprints.

Publisher's note Springer Nature remains neutral with regard to jurisdictional claims in published maps and institutional affiliations.

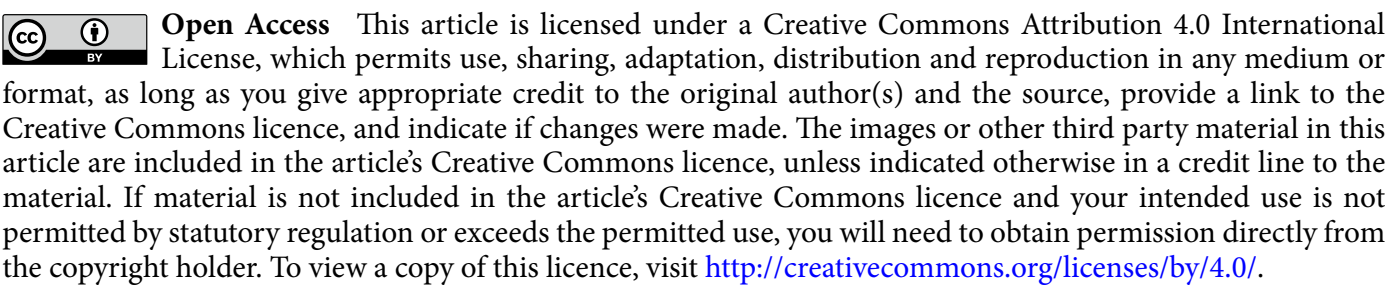

(C) The Author(s) 2020 